\title{
"HOMO-MARSKIN" PÄIVÄT MEDIAMYRSKYN SILMÄSSÄ
}

\section{HANKALA SEKSUAALISUUS URALIN PERHOSEN VASTAANOTOSSA ${ }^{1}$}

Nukkeanimaatio Uralin perhonen nostatti kevättalvella 2008 Suomessa kiibkeän mediamyrskyn. Katariina Lillqvistin objaama animaatio kertoo "suurimmaksi suomalaiseksi" valitusta Carl Gustaf Emil Mannerheimista selvästi kansallisista suurmieskertomuksista poikkeavan tarinan. Se esittelee aktiivisesti vuoden 1918 sisällissodan punaisten teloituksiin osallistuvan marsalkka Mannerheimin. Elokuvassa annetaan myös ymmärtää, että Mannerheimilla olisi ollut homoseksuaalinen subde "Uralin perhoseksi" nimetyn kirgisialaisen palvelijansa kanssa. Lisäksi Uralin perhosessa sivutaan transvestisuutta Mannerheimin pukeutuessa siinä purppuranpunaiseen korsettiin.

Artikkelissa tarkastellaan, miten Uralin perhosen mediavastaanotossa kirjoitettiin ja pubuttiin seksuaalisuudesta ja miten seksuaalisuuden merkityksistä neuvoteltiin Suomen mediassa Uralin perhosen vastaanoton sekä siihen sidoksissa olevan Mannerheimin henkilökuvan kautta. Artikkelin aineisto koostuu ybteensä neljästäkymmenestä suomalaisten sanoma- ja iltapäivälebtien internetissä julkaisemasta uutisesta, artikkelista ja arvostelusta, muista internetissä julkaistuista teksteistä sekä Yleisradion TV 1:ssä esitetystä A-talk-keskusteluohjelmasta. Uralin perhosen vastaanoton tutkimuksen lisäksi artikkelissa esitellään sitä edeltäneitä ja sille rinnasteisia taiteen mediakobuja ja kulttuurisotia. Uralin perhosta ja sen vastaanottoa tarkastellaan osana laajempaa kulttuurisotien jatkumoa, jossa on käyty jatkuvaa neuvottelua taiteen sananvapaudesta sekä taiteen ja kulttuurin sensuroimisesta.

Uralin perhosta paheksuttiin mediassa voimakkain ja tuomitsevin ä̈nenpainoin. Etenkin siinä kuvatusta normienvastaisesta seksuaalisuudesta kirjoitettiin provokatiivisesti ja provosoituneesti. Marskin päivät mediamyrskyn silmässä osoittavat, että suomalainen sotasankaruus, kansallishistoria ja kansallisuus näyttäytyvät monissa yhteyksissä edelleen muuttumattomina, järkkymättömästi pybinä ja jalustalle asetettuina ihannekuvina. Taiteen tai sen esittelemien normienvastaisten seksuaalisuuksien ei sovi niitä horjuttaa. Toisaalta kulttuurisotien kontekstissa Marskia koskevaa mediamyrskyä voidaan lukea myös seksuaalisuuden kulttuurisia merkityksiä ja rajoja koettelevana ilmiönä. 
"Marski-salin seinällä on Akseli Gallen-Kallelan maalaus marsalkka Mannerheimista. Marski on frakissa komea, mutta kukaan ei ole hänestä kiinnostunut", kirjoitti Helsingin Sanomien politiikan toimittaja Unto Hämäläinen blogissaan vuonna 2007. Nämä pääministeri Matti Vanhasen entisen naisystävän Susan Kurosen Pä̈ministerin morsian -teoksen (2007) kansien julkistamistilaisuuteen viittaavat sanat tuntuvat nyt, niitä jälkikäteen arvioitaessa ja kontekstistaan irrotettuina, suorastaan enteellisiltä. Tasan vuoden päästä tilanne oli lähes täsmälleen päinvastainen: Carl Gustaf Emil Mannerheimista näytti olevan kiinnostunut yksi, jos toinenkin. Suomen valtakunnassa elettiin kevättalvella 2008 yllättäen jopa median kestosuosikeiksi muodostuneiden poliitikoiden ja heidän vaihtuvien puolisoehdokkaidensa medianäkyvyyden (vrt. Karvonen 2006; Juntunen \& Väliverronen 2008) ylittävää marskimyrskyä. Harvinaisen monella oli tarve kertoa oma näkemyksensä siitä, kuka ja mitä Mannerheim "oikeasti” oli - ja keitä hänen intiimeiksi seuralaisikseen on julkisesti sopivaa esittää.

Ihmisten paikoitellen suorastaan pakottavalta tuntuvia tarpeita sanoa sanottavansa Mannerheimista herätteli Katariina Lillqvistin, muun muassa Taiteen valtionpalkinnolla palkitun animaatio-ohjaajan, nukkeanimaatio Uralin perhonen (2008). Tämä Tampereen kansainvälisen lyhytelokuvafestivaalin kotimaisessa kilpailussa parhaana palkittu animaatio kertoo Mannerheimista tarinan, joka poikkeaa selvästi niistä kansallisista suurmieskertomuksista, joihin olemme tottuneet. Animaatiossa esitellään vuoden 1918 sisällissodan ${ }^{2}$ punaisten teloituksiin aktiivisesti osallistuva Suomen marsalkka Mannerheim. "Lahtari-Marski" osoittautui Uralin perhosen vastaanotossa melkoiseksi kipupisteeksi, jota kritisoitiin mediassa taajaan. Animaation sanottiin sekä loukkaavan Mannerheimin, "suuren suomalaisen", muistoa että välittävän sota-aikaisten neuvostoliittolaisten filmatisointien propagandaa. Se määriteltiin muun muassa puna-armeijan propagandan perilliseksi, ja sen sanottiin sytyttäneen Suomessa "uuden sisällissodan" tai "kansalaissodan". (AL 2008c, d; A-talk 2008; Dahlbäck 2008; IS 2008a; Paasonen 2008b; Parkkari 2008b.)

Punaisia teloittavan "lahtari-Marskin" ohessa toiseksi animaation kipupisteeksi muodostui siinä esitetty Mannerheimin normienvastainen seksuaalisuus ja transvestisuuteen viittaava viehtymys naisten alusasujen käyttöön. Animaatio antaa ymmärtää, että Mannerheimilla olisi ollut homoseksuaalinen suhde kirgisialaisen, elokuvassa nimenomaan "Uralin perhoseksi" kutsutun palvelijansa kanssa, jonka seurassa hän esiintyy purppuranpunaiseen korsettiin pukeutuneena. Uralin perhosen ensi-iltaa edeltäneinä ja seuranneina helmi- ja maaliskuun päivinä internetissä julkaistiin runsaasti sitä käsitteleviä iltapäivä- ja sanomalehtiuutisia, ja siitä kirjoitettiin ahkerasti joukkotiedostusvälineiden hallinnoimilla internet-keskustelupalstoilla. Etenkin animaatiossa esiintyvästä seksuaalisuudesta kirjoitettiin varsin provokatiivisesti ja provosoituneesti, mikä näkyi selvästi otsikoissa: "Mannerheim on elokuvassa homo" (Salminen 2008),"Homo-Mannerheim kohauttaa Yleisradion ohjelmassa!" (IL 2008a),"'Homo-Marski' herätti pahennusta myös eduskunnassa" (MTV3-STT 2008), "Ei voi olla totta: Homo-Marski tukki koko teatterin!" (AL 2008a).

Tarkastelen tässä artikkelissa sitä, mitä Uralin perhosen mediavastaanotossa kirjoitettiin ja puhuttiin seksuaalisuudesta: miten seksuaalisuuden 
merkityksistä neuvoteltiin Suomen mediassa Uralin perhosen vastaanoton ja siihen sidoksissa olevan Mannerheimin henkilökuvan kautta. Tutkimusaineistoni koostuu yhteensä neljästäkymmenestä sanoma- ja iltapäivälehtien internetissä julkaisemasta uutisesta, artikkelista ja arvostelusta. ${ }^{3}$ Lisäksi aineistoon kuuluu Yleisradion TV 1:ssä 6.3.2008 esitetty A-talk-ajankohtaisohjelma, jonka aiheena oli Uralin perhonen. ${ }^{4}$ Keskusteluun osallistuivat toimittaja Jan Anderssonin johdolla Uralin perhosen ohjaaja Katariina Lillqvist, Vasemmistoliiton kansanedustaja Minna Sirnö, entinen Suomen puolustusvoimain komentaja, kenraali Gustav Hägglund sekä Kristillisdemokraattien kansanedustaja ja eduskuntaryhmän puheenjohtaja Bjarne Kallis. Ohjelman inserteissä haastateltiin Seta ry:n puheenjohtajaa Juha Jokelaa ja Svenska Teaternille Mannerheim-näytelmän käsikirjoittanutta Per-Erik Lönnforsia.

Uralin perhosen mediavastaanoton ja siinä kiihkeästi neuvoteltujen seksuaalisuuden merkitysten tarkastelun lisäksi esittelen Uralin perhosta edeltäneitä ja sille rinnasteisiksi muodostuvia taiteen mediakohuja ja kulttuurisotia. Tavoitteenani on asettaa Uralin perhonen ja siihen kohdistunut mediakohu osaksi laajempaa kulttuurisotien jatkumoa, jossa on käyty jatkuvaa neuvottelua taiteen- ja sananvapaudesta ${ }^{5}$ sekä sensuurista ${ }^{6}$.

\section{ALKUVASTAANOTON PROVOKAATIOTA, PROVOSOITUMISTA JA PUOLUSTUSTA}

Lillqvistin mukaan hänen ohjaamansa animaation tavoitteena on ollut tuoda julkiseen keskusteluun myös Mannerheimin niin sanottu"pimeä puoli”. Tällä Lillqvist on korostanut sitä, että pitää yhtenä tärkeänä tehtävänään Suomen sisällissodan hävinneiden historian taltioimista ja kertomista - eikä siis niinkään Mannerheimin seksuaalisuuden esilletuomista, jota useat mediassa julkaistut otsikot korostivat. ${ }^{7}$ (Hemming 2008; Silén 2008.) Lillqvist toteaa:

Onhan Uralin perhonen poliittinenkin elokuva, kun se puhuu hävinneiden historian unohdusta vastaan. Nyt on ensimmäistä kertaa pystytty purkamaan tätä historiaa, kun teos on herättänyt ihmiset kuulemaan näitä tarinoita. Ehkä Suomessakin ollaan siirtymässä sellaiseen mannermaiseen keskustelutyyliin, jolla vaikeista asioista voidaan puhua. (Sit. Hemming 2008.)

Tarkasteluni lähtökohta on Lillqvistinkin esille tuomassa Uralin perhosen poliittisuudessa. ${ }^{8}$ Sen lisäksi, että animaatio on poliittinen uudelleen- tai toisinkirjoittaessaan poliittista historiaa, se on sitä väistämättä myös seksuaalisuuden, sukupuolen historian sekä sukupuoli- ja seksuaalipolitiikan näkökulmista. Paitsi että Uralin perhonen kertoo tarinallaan toisenlaista, perinteisistä historiankirjoituksista poikkeavaa sisällissodan hävinneiden historiaa - ja erityisesti sodassa toimineiden naisten historiaa - se tekee näkyväksi myös aiemmin salattua ja vaiettua, normienvastaisten seksuaalisuuksien historiaa (vrt. esim. Juvonen 2002). Tämä historia tulee julkiseksi Mannerheimin henkilökohtaisissa suhteissa, joihin median otsikoissakin provokatiivisesti tartuttiin. 
Uralin perhonen sai mediassa provokatiivisen ja provosoituneen alkuvastaanoton muutenkin kuin lehtijuttujen otsikoissa. Ensimmäiseksi mediatilaa saivat animaatiota paheksuvat ja tuomitsevat äänenpainot. Eturintamassa paheksuntaansa ja tuomiotaan oli esittämässä Helsingin entinen ylipormestari, Kokoomuksen Raimo Ilaskivi (2008). Hän vaati Uudessa Suomessa "Mannerheimin häpäisijöitten pä[itä] pölkylle", mitä hän edellytti tehtäväksi "maan historian oikean kirjoituksen ja sen merkkihenkilöitten kunnian turvaamisen vuoksi". Keskusteluihin vedettiin mukaan myös Suomen Marsalkka Mannerheimin perinnesäätiö. Organisaation toiminnanjohtaja Janne Kososelta ehätettiin saada lausunto, jonka mukaan "tällaista elokuvaa ei pitäisi tehdä", jo ennen kuin hän oli nähnyt animaatiota (Salminen 2008). Animaation nähtyään hänen vielä kerrottiin olevan "hyvin surullinen". "[K] ovin osoitteleva[n]" elokuvan sanottiin aiheuttavan "isolle osalle suomalaisista pahaa oloa ja pahan tunnelman". (IL 2008a; IL-STT 2008; Koponen 2008a; Salminen 2008; Tolonen 2008.)

Sittemmin keskusteluun osallistui samassa hengessä, niin ikään ensi alkuun animaatiota näkemättä, kenraali Gustav Hägglund. Hänet esitettiin mediassa toistuvasti tuohtuneena kieltämässä Mannerheimin homoseksuaalisuus ja kehottamassa animaation tekijää häpeämään:

Yrittääkö hän herättää huomiota ja saada myydyksi tätä juttua. Yritetään shokeraata [sic] ihmisiä tälläisillä [sic] huuhaajutuilla. - Kyllä tämä loukkaa ja se on ollut varmaan tarkoituskin. - - Saisi hävetä." (AL 2008g; ks. myös AL 2008c; IS 2008a.)

Entinen puolustusvoimien komentaja Gustav Hägglund kehotti - - elokuvan tekijöitä häpeämään. Hägglundin mukaan on yleisesti tunnettua, että Mannerheim ei ollut homo - . . (Tikka 2008a.)

Kansanedustaja Bjarne Kallis otti animaation esille eduskunnan kyselytunnilla. Hän penäsi sen rahoituskelpoisuutta sekä rahoituksen myöntäjien vastuuta, kun ”[e]duskunnan valvonnassa olevan Yleisradion osin rahoittamassa elokuvassa marsalkka esitetään julkisuudessa olleiden tietojen mukaan 'korsettiin pukeutuvana homoseksuaalina', joka viihtyy hyvin miespuolisen sotilaspalvelijansa kanssa". (Kallis 2008; Kristillisdemokraatit 2008: MTV3-STT 2008.) Vastaavanlainen eetos leimasi muidenkin Uralin perhosen ja Lillqvistin kritisoijien kannanottoja, esimerkiksi:

Täyttä roskaa! Miten tuollaista saadaan edes Suomessa esittää? Luulisi, että sitä on jokin raja olemassa, puuskahtaa Mannerheim-ristin ritari tuohtuneena. / Iisalon mukaan elokuva ei edusta Suomen kansan näkemystä Mannerheimista. / - Jokainen tietää, että elokuva on puppua. Moni sotaveteraani kääntyisi haudassaan, jos he tietäisivät, mitä tälllä tapahtuu. En yksinkertaisesti ymmärrä, miksi tällaisia pilkkaohjelmia pitää tehdä? (Parkkari 2008b; ks. myös AL 2008c, g, h; Dahlbäck 2008; Earl 2008; Ilaskivi 2008; Taponen 2008.) 
Lopulta uutisoitiin, että Uralin perhosta on vaadittu jopa sensuroitavaksi (AL 2008a, h) ja ettei animaatiota näytetä sen osarahoittajan, Yleisradion, kanavalla itsenäisyyspäivänä 2008, kuten alustavasti oli ainakin ohjaajan sanojen mukaan suunniteltu (AL 2008e; Dahlbäck 2008; Tikka 2008a). Yleisradion toimitusjohtaja Mikael Jungner ilmoitti yksitotisesti, että "[i]tsenäisyyspäivänä Suomi kunnioittaa sankareitaan". Hän perusteli päätöstä vielä sillä, että "Mannerheim on kansakunnan sankari. Hän on ollut sitä minullekin, pikkupojasta asti”. (AL 2008e; Tikka 2008a; TS 2008.) Myös oikeuskanslerin virasto joutui lopuksi ottamaan kantaa siihen, loukkaako Uralin perhonen ja sen esittäminen entisen tasavallan presidentin kunniaa ja mainetta (HS.fi-STT 2008; IS 2008b). ${ }^{9}$

Ensimmäisten paheksuvien uutisten jälkeen useissa lehtiartikkeleissa otettiin kaikki irti varsinkin Uralin perhosen "homo-Marskista" loukkaantuneiden julkisista kannanotoista:

Katariina Lillqvistin animaatioelokuva "Uralin Perhonen" on herättänyt paljon kohua. Elokuva esittää kansallisen ikonimme Mannerheimin korsettiin pukeutuvana homoseksuaalina. (Paasonen 2008b.)

Vuoden 1918 sisällissodasta kertovan elokuvan yhtenä teemana on Carl Gustaf Emil Mannerheimin seksuaalielämä. Sotiemme ylipäällikkö ja kansallinen sankari esitetään elokuvassa homoseksuaalina. / Pyhäinhäväistys on saanut varsinkin nettikirjoittajat raivostumaan -.. (IS-STT 2008.)

[V]iittaukset Mannerheimin homoseksuaalisiin taipumuksiin ovat kuumentaneet tunteita. - - Mannerheim ihastuu ja tuo poikaystävän kaukomatkoiltaan mukanaan kotiin. Kuten Mannerheimin puoliso Anastasia toisaalla elokuvassa toteaa:"Mieheni intohimon kohteena oli nyt lukutaido[to]n paimenpoika Uralin takaa." (AL 2008h.)

Uralin perhosta paheksuvien lisäksi myös Lillqvist ja häntä sekä animaatiota puolustavat saivat puheenvuoroineen oman tilansa mediassa (esim. AL 2008g, f; Avola 2008; Dahlbäck 2008; Hemming 2008; Hällsten 2008; Koponen 2008a; Lillqvist 2008a, b; MTV3.fi 2008; MTV3-STT 2008; Määttänen 2008; Paasonen 2008a; Räikkä 2008; Tolonen 2008). Lillqvistiä haastateltiin ja haastettiin vastaamaan animaatioon kohdistettuihin syytöksiin, joihin hän vastasikin - alkuun hieman hämmentyneenä:

Suomessa on aika huono henkinen ilmapiiri. Jos ihmiset pillastuvat Mannerheimista näin paljon, onhan se aika huolestuttavaa, Lillqvist sanoo. / - - Animaation pointti ei edes ole Mannerheimin mahdollinen homous vaan aivan muut asiat. Elokuva käsittelee enemmän yksinäisyyttä, rakkauden kaipuuta ja sotahulluutta kuin Marskin seksuaalisia mieltymyksiä. (Parkkari 2008b.) 
Yksi Lillqvistin puolustajista, Helsingin yliopiston historian professori Laura Kolbe, peräänkuulutti tämän vapautta taiteilijana. Samalla Kolbe otti kantaa Uralin perhosen tapaan käsitellä Mannerheimin seksuaalisuutta:

Se on hänen oikeutensa intellektuellina ja luovana ihmisenä: katsoa juuri ilmiöiden taakse ja avata keskustelua. - - Kolben mukaan Marski kaadettiin jalustaltaan jo 1960-1970 lukujen arvovallankumouksen myötä. / - Se oli poliittista, hänestä tehtiin oikeistolainen lahtarikenraali ja se vastasi aikakauden henkeä. / - Tämän aikakauden henkeä ehkä vastaa se, että katsotaan ihmisen seksuaalista suuntautumista ja hänen petipuuhiaan -.. (Paasonen 2008b.)

Myös Lillqvist lähti puolustamaan animaatiotaan julkisesti. Hän muun muassa julkaisi internetissä avoimen kirjeen, jossa vetosi ponnekkaasti etenkin taiteen- ja sananvapauteen. "Sananvapausterveisin" allekirjoitetussa kirjeessä Uralin perhosta koskevan keskustelun ennustetaan kasvavan suurimmaksi debatiksi sensuurista ja sananvapaudesta vuosiin. (Lillqvist 2008a; MTV3.fi 2008.) Sananvapauden ja siihen välittömässä suhteessa olevia sensuurin kysymyksiä onkin syytä pohtia Uralin perhosen vastaanoton tarkastelun yhteydessä tarkemmin. Sitä ennen kuitenkin vielä muutama sana siitä, mitä Mannerheimin seksuaalisuudesta Uralin perhosen vastaanoton alkuhälyn jälkeen sanottiin Yleisradion A-talk-keskusteluohjelmassa (2008).

\section{RISTIRIITOJA JATKOVASTAANOTOSSA}

Marskin päivät mediamyrskyn silmässä jatkuivat Uralin perhosesta syntyneen tuohtumuksen synnyttämän, lähinnä lehtiin ja internetiin paikantuneen alkuhälyn jälkeen myös televisiossa. Yleisradion A-talk-ohjelmassa aihetta puitiin kuitenkin hieman seesteisemmissä ja maltillisemmissa tunnelmissa. Muun muassa Hägglund halusi korjata keskustelun aikana hänen mediassa aiemmin väärin tulkittua seksuaalisuuslausuntoaan. Hän ei ollut sanojensa mukaan varsinaisesti kieltänyt Mannerheimin mahdollista homoseksuaalisuutta, vaan ainoastaan todennut, että "Mannerheim oli tunnettu naissuhteistaan" (vrt. esim. Tikka 2008a). Hägglundin mukaan "[e]i ole löytynyt todisteita, että Mannerheimilla olisi ollut miesrakastajia", ja siksi ajatus tämän homoseksuaalisuudesta "tuntuu" hänestä "fiktiolta" ja "epätodennäköiseltä" mutta että mahdollista homoseksuaalisuuskin voi silti tietysti olla. (A-talk 2008.)

Hägglundin lausuntokorjailuista huolimatta seksuaalisuusaiheen käsittely jäi A-talkin keskustelussa ristiriitaiseksi. Vaikka Hägglund halusi oikaista lehdissä julkaistuja tulkintoja omista puheistaan ja homovastaisiksi mielletyistä lausunnoistaan, hän päätyi ohjelman aikana kyseenalaistamaan tai vastustamaan ajatusta Mannerheimin mahdollisesta homoseksuaalisuudesta. Hän muun muassa totesi, ettei vakuutu perustelusta, jonka mukaan Mannerheim olisi ollut homoseksuaali siksi, että viihtyi kauniiden ja älykkäiden naisten seurassa. Hän vasta-argumentoi asiaa omalla heteroseksu- 
aalisuudellaan: "Minäkin viihdyn kauniiden ja älykkäiden naisten seurassa ja varmasti olen hetero." (A-talk 2008; ks. myös Uusi Suomi 2008.)

Bjarne Kallis puolestaan toisti puheenvuoroissaan Mannerheimiin liitettyjä fraaseja "Suomen itsenäisyyden symboli", "suurmies" ja "Suomen pelastaja sadoilletuhansille, ehkä miljoonille" sekä kysymystä:"Minkä takia pitää loukata suuria kansalaisryhmiä, veteraanipolvea?" Kallis kuitenkin vältti sanomasta, mikä animaatiossa niin kovin loukkasi, ja ainoastaan (kierto-) ilmaisi useaan otteeseen, ettei ymmärtänyt, miksi Mannerheimin "pimeät puolet" täytyi tuoda julkisuuteen. Hänen mielestään veteraaneja ja "vanhempaa polvea" ei saa tietoisesti loukata. Ohjelman erillistä inserttiä varten haastateltu Seta ry:n puheenjohtaja Juha Jokela toi tähän Kalliksen hokemaan kuitenkin sitä toisintoistavan särön todetessaan, että hänen mielestään on rintamalla Suomea puolustaneita homoveteraaneja kohtaan loukkaavaa määritellä homoseksuaalisuus loukkaavaksi. (A-talk 2008.)

Suurin huolenaihe sekä Hägglundille että Kallikselle tuntui animaation osalta olevan se, että "suurin suomalainen kautta aikojen, suurmies, joka takasi sen, ettei Suomesta tullut Neuvosto-Suomea, - - viedään lokaan [ja] häpäistään". Ja mikäpä viekään suurinta suomalaista paremmin lokaan kuin seksuaalisuus? Näin ainakin, jos Hägglundia ja Kallista on uskominen. Kallis toteaa kyllä, että "[en] puhu homoudesta, totean vain, että on loukattu", mutta kysyy lähes samaan hengenvetoon: "Jos hän ei ollut homo, miksi täytyy antaa sellainen kuva?" Hägglund puolestaan tavoittelee lausumassaan ilmeisesti humoristiseksi tarkoitettua tyylirekisteriä: "Överiksi menee, jos joku kirgiisi bylsii Suomen tulevaa presidenttiä." Kun Hägglundilta ja Kallikselta kysytään, muuttuisivatko heidän ilmeisen arvostavat käsityksensä Mannerheimista, jos saataisiin tietää tämän olleen homoseksuaali, he molemmat ilmoittavat, että näin ei missään tapauksessa kävisi. Siitä huolimatta tilanne näyttää täsmälleen siltä kuin kansanedustaja Sirnö heille ohjelmassa ehdottaa: kun pintaa vähän raaputetaan, esille putkahtavat vanhat homofobiat. (A-talk 2008.)

Nykykulttuuri osoittaakin tapauksessa nurinkurisuutensa. Nykyisin ei ole enää seksuaalipoliittisesti korrektia olla julkisesti homofobinen, ja homovastaiset puheet täytyy kieltää. Ollakseen julkisuudessa suhteellisen vakavasti otettava ja varteenotettava vanhakantaisiksi leimautuvat homofobiat täytyy pitää kaapissa. On mielenkiintoista, että homoseksuaalisuudella on takanaan jo pitkä kieltämisen kaapitettu historia, joka tuntuu vain jatkuvan, joskin uudessa muodossa. Homoseksuaalisuus on ollut Suomen laissa kiellettyä, siis rikollista, vuoteen 1971, ja sen jälkeenkin homoseksuaalisuus on täytynyt enimmäkseen julkisesti kieltää tai pitää kaapissa. Sen sijaan nyt, kun eletään itse Hägglundinkin sanoin kohtuullisia suvaitsevuuden aikoja (A-talk 2008), kiellon kohteeksi joutuu homoseksuaalisuuden sijaan vanhakantaiseksi leimautuva homofobia. Näin homoseksuaalisuus kietoutuu edelleen kiellon ja kieltämisen myytilliseen auraan, mutta toisin toistettuna. 


\section{URALIN PERHONEN KULTTUURISOTIEN JA -SENSUURIEN JATKUMOSSA}

On kiinnostavaa pohtia, miksi Uralin perhosessa käsitellyt aiheet kohahduttivat ja kuohuttivat tunteita ja aiheuttivat mediassa jopa hienoisen kulttuurisodan. Suurenkin yleisön kun luulisi jo olevan suhteellisen tottunutta homoseksuaalisuuden mediaesityksiin, joita Uralin perhonen kotikatsomoihin tarjoili. ${ }^{10}$ Edes vuoden 1918 tapahtumien, joihin animaatio ottaa voimakkaasti kantaa, ei pitäisi olla enää yhtä tulenarkoja keskustelunaiheita kuin muutama vuosikymmen sitten (Salminen 2007, 224), ja "suurmies"Mannerheimistakin on tehty esimerkiksi parodista ja groteskia satiiria jo aiemmin (ks. myös Hurri 1993, 125; Lyytikäinen 2004, 214, 220). Itse asiassa Uralin perhosen tarina on esitetty Lillqvistin ja Hannu Salaman käsikirjoittamana radiokuunnelmana jo vuonna 2004 Yleisradion Todellisia tarinoita -sarjassa, ja se edusti Suomea Prix Italy -kilpailussa Milanossa, mutta tuolloin asiaan ei kiinnitetty erityistä mediahuomiota (Lillqvist 2008b; Hällsten 2008).

Miten vuoden 2008 "Mannerheim-skandaaliksikin" nimettyä ( $A L$ 2008c) tapahtumasarjaa sitten voidaan selittää? Artikkelini loppuosassa tarkastelen Uralin perhosen vastaanoton kulttuurista kontekstia. Taustoitan Uralin perhosen mediavastaanottoa sitä edeltävien, vastaavan tyyppisten taiteen mediakohujen tai kulttuurisotien esittelyn kautta ja analysoin niiden ja Uralin perhosen vastaanoton välisiä temaattisia yhteyksiä. Tutkimuksen kohteena ovat Uralin perhosen vastaanoton lisäksi näin hieman laajemmin kulttuurisodiksi nimetyt tapahtumasarjat tai ilmiöt sekä niihin kytkeytyvät keskustelut, joissa on käyty kiivastakin sananvaihtoa taiteen vapaudesta ja vastavuoroisesti sen sensuroimisesta. Asetan Uralin perhosen osaksi tätä kulttuurisotien jatkumoa, jossa on käyty jatkuvaa neuvottelua myös sananvapaudesta.

Tunnetuimpia kulttuurisotia ennen Uralin perhosen synnyttämää "uutta kansalaissotaa" tai "sisällissotaa", kuten A-talk-ohjelman (2008) toimittaja Jan Andersson asian muotoili, ovat olleet Suomessa muun muassa Väinö Linnan Tuntemattoman sotilaan (1954) sytyttämä "kirjallinen jatkosota" sekä Hannu Salaman löyhämoraalista seksuaalisuutta ja jumalanpilkkaa viljelevästä Jubannustansseista (1964) syttynyt "Salama-sota" oikeudenkäynteineen ja presidentinarmahduksineen (Hurri 1993, 95-97; 136142). Mielenkiintoisen, Uralin perhosen herättämälle kohulle rinnasteisen ja sitä ehkä selittävänkin kohun aiheutti Suomessa jo sata vuotta sitten Ville Vallgrenin Havis Amanda, Helsingin kauppatorille vuonna 1908 sijoitettu suihkulähde, jossa seisovan naispatsaan alastomuus ja julkeus saivat osakseen voimakasta paheksuntaa. Taidehistorioitsija Harri Kalhan tutkimassa suihkulähdekiistassa käytiin laajalti keskustelua"taiteesta ja turmelluksesta, suomalaisuudesta ja vieraista vaikutteista, sopivaisuudesta ja sopimattomuudesta, vallasta ja vallattomuudesta" - pitkälti samoista aiheista kuin Uralin perhosen sytyttämässä kulttuurisodassa. Kalha esittää Havis Amandan kulttuurisotatapauksen voiman kumpuavan kahdesta: aikamme siveellisyyskäsityksestä ja suhtautumisestamme kuvien valtaan. (Kalha 2008, 16-25, 181.) Samojen asioiden parissa liikumme väistämättä myös Uralin perhosen tapauksessa. 
Viimeisimpiä vastaavanlaisia, Uralin perhosen synnyttämää "uutta kansalaissotaa" edeltäneitä ja Havis Amandan suihkulähdekiistaa seuranneita kulttuurisotia, joita käydään nykyisin entistä enemmän mediassa ja median välityksellä ja aivan erityisesti internetissä, ovat sytyttäneet muun muassa Teemu Mäen kissantappovideoksi nimetty mediataideteos, jossa Mäki hakkaa kissanpennun kuoliaaksi kirveellä ja ejakuloi tämän jälkeen sen päälle (ks. Mäki 2005), Ville Rannan sarjakuvan Mubammed, pelko ja sananvapaus (2006) julkaisemisesta liikkeelle lähtenyt, "Suomen Muhammed-kohuksi" nimetty (Seppä 2007) tapaus sekä Ulla Karttusen Neitsythuorakirkko-teoksen (2008) takavarikointitapaus, josta uutisoitiin näyttävästi mediassa. ${ }^{11}$

Näiden kulttuuri- tai mediasotien seurauksena Mäki tuomittiin oikeudessa eläinrääkkäyksestä ja elokuvatarkastamo kielsi hänen teoksensa julkisen esittämisen. Rannan sarjakuva poistettiin pysyvästi pohjoisen kulttuurilehti Kaltion kotisivuilta ${ }^{12}$ ja Karttuselle langetettiin hänen työnsä takavarikoinnin jälkeen syyte lapsipornon hallussapidosta. Kaikissa näistä teoksista käydyissä mediakeskusteluissa sekoittuivat monitasoisesti poliittisuuteen, mutta sen lisäksi myös taiteen vapauteen ja sensuroimiseen sekä sananvapausoikeuteen liittyvät problematiikat. Risto Kuneliuksen $(2007,21)$ sanoin "[j]ournalismi ja sen soveltama sananvapaus elävät aikaa, jossa valinnat politisoituvat yllättävin tavoin". Samalla tavalla näyttäisi käyvän usein myös taiteessa ja siitä käydyissä mediakeskusteluissa. Esimerkiksi Mäen videoteoksessa, Muhammed, pelko ja sanavapaus -sarjakuvassa ja Neitsythuorakirkkoteoksessa sekä niistä käydyissä kiivaissa keskusteluissa yhdistyvät Uralin perhoseen liittämääni kolmenlaiseen politiikkaan - seksuaalipolitiikkaan, sukupuolipolitiikkaan ja poliittiseen historiaan - sitoutuvat erityispiirteet. (Mäki 2005; Mellais ym. 2008; Seppä 2007; Sevänen 2008; Tontti 2008.) Tämän lisäksi ne kaikki ovat aiheuttaneet osaltaan mediakohun, ja niitä yhdistää suhde sensuuriin tai sensurointiin: ne ovat kaikki joutuneet joko sananmukaisesti tai ainakin julkisen spekulaation tasolla sensuroinnin kohteiksi.

Taiteen sensuroinnissa tai sitä koskevissa sensurointipyrkimyksissä ja -spekulaatioissa on useimmiten vedottu kyseessä olevien teosten rienaavuuteen. Sensuroinnin perusteluiksi esitetään muun muassa seksuaalisuuden, säädyttömyyden ja moraalittomuuden kuvauksia sekä teosten tapaa kyseenalaistaa uskontoa tai horjuttaa perinteisiä isänmaallisia arvoja. ${ }^{13}$ Lisäksi Suomessa "väränlainen" (ulko-)politiikka on usein johtanut sensurointiin. (Hurri 1993, 290-291; Sedergren 2004, 273; Ekholm 2005.) Vääränlaisen poliittisuuden sensuroiminen ja erityisesti itsesensuuri selittyvät pitkälti Suomen sotahistorialla ja maantieteellisellä asemalla Neuvostoliiton kyljessä. Toisen maailmansodan jälkeinen kylmän sodan kausi vaikutti aina 1990-luvulle asti sekä ulkopolitiikkaan että siihen, miten Suomessa uskaltauduttiin kirjoittamaan Neuvostoliitosta. (Salminen 2003; Sedergren 2004, 268-269.) Silloinen, esimerkiksi toimittajien harjoittama, ulkopoliittisena korrektiutena näyttäytyvä itsesensuuri mahdollisti pitkälti Suomelle olemassaolon poliittisena, kansallisena ja kansainvälisenä toimijana. Kyse on siis ollut sopeutumisesta vallassa olevan linjaan (vrt. Hurri 1993,286). Mari Maasilta on kuitenkin muistuttaa oikeutetusti, että itsesensuuri on sensuureista kaikista vaarallisinta eritoten siksi, että sen perustuu yleensä pelkoon (Maasilta 2007, 195; ks. myös Salminen 2003). Vielä nykyisinkin suomalaista yhteiskuntaa 
ja kulttuuria on luonnehdittu toisinaan "Kekkosslovakian mentaliteetin" ja "suomettumisen" kyllästämiksi (esim. Kunelius 2007, 27; Tontti 2008). Tätä taustaa vasten on ehkä helpompi selittää ja ymmärtää Suomessa läsnä olleita erikoislaatuisia, taiteeseen säännöllisin väliajoin kohdistuneita kulttuurisotia ja niihin kytkeytyneitä sensurointipyrkimyksiä, joissa monitasoisella politiikalla on usein merkittävä rooli.

Mäen, Rannan ja Karttusen provokatiivisten teosten, jotka siis kritisoivat muun muassa yhteiskunnan ja kulttuurin valtajärjestelmiä, uskontoa, väkivaltaa, yhteiskunnan yliseksualisoitumista tai pornoistumista ja lapsipornoa, jopa hieman hätiköidyltä tuntuvat syytteet ja suoranaiset sensurointitoimet kuvastavat jotenkin oireellisesti suomalaiseen taiteeseen ja kulttuuritoimintaan liittyvää sananvapauden nurinkurista historiaa. Ne tekevät näkyväksi Suomen historiaa, jota ovat varjostaneet naapurivaltioiden valtapyrkimykset, monet sodat ja maailmanpolitiikan epävakaat suhdanteet. Suomessa on totuttu niin taiteen ja kulttuurin kuin politiikankin alueilla aktiiviseen itseja ennakkosensuuriin (ks. esim. Salminen 2003), jonka perinteeseen näyttävästi provokatoriset, jopa lakeja uhmaavat teokset ja toimet eivät oikein sovi. Tässä perinteessä kenenkään ei tulisi taiteen nimissä loukkaantua, järkyttyä tai pahoittaa mieltään, mitä todistaa myös esimerkiksi Suomen nopea ja lopulta turhaksi ja kiusalliseksikin osoittautunut omaehtoinen aktiivisuus maailmanlaajuisessa, Tanskasta liikkeelle lähteneessä Muhammed-sarjakuvakohussa: Suomi meni ja pyysi omasta puolestaan kohua anteeksi (Kunelius 2007, 27) ${ }^{14}$ Turhan ja kiusallisen julkisesta anteeksipyynnöstä teki se, ettei Suomella ollut alun pitäen jupakassa osaa eikä arpaa. Rannan sarjakuva Mubammed, pelko ja sananvapaus kritisoi sattuvasti täsmälleen tätä suomalaista, syklisesti toistuvaa konsensushenkistä (vrt. Hurri 1993, 300), voimakkaampien valtiomahtien rinnalla tottuneesti harjoitettua, lähinnä pelkoon pohjautuvaa (ulko)politiikkaa.

\section{HANKALA SEKSUAALISUUS MANNERISTA MANNERHEIMIIN}

Varsinkin ulkopolitiikkaa, uskontoa tai kansallisuuden ihannetta kritisoiva taide on siis paikoin ollut Suomessa kovilla. Sama on koskenut taidetta, joka haastaa yhteiskunnallisia sopivaisuuden sääntöjä tai lakeja ja asetuksia, sekä seksuaalisuutta avoimesti käsittelevää taidetta. Ehkä järjestelmällisimpiä sensurointitoimenpiteitä ovat - varsinkin kirjallisuuden historiassa - joutuneet kohtaamaan teokset, joissa käsitellään normienvastaista seksuaalisuutta, tavallisimmin homoseksuaalisuutta tai lesboutta. Vielä muutama vuosikymmen sitten elettiin tilanteessa, jossa tällaiset teokset suljettiin konkreettisesti kaappeihin ja lukkojen taakse, suuren yleisön saavuttamattomiin (Kekki 2006; ks. myös Sedergren 2004, 274).

Suomalaisena, tilanteen systemaattisuutta osoittavana kirjatapauksena voisi pitää Helvi Hämäläisen jo vuonna 1927 kirjoittaman romaanin Kaunis sielu julkaisemista vasta vuonna 2001. Kustantaja oli hylännyt eli toisin sanoen ennakkosensuroinut teoksen aiemmin sen arkaluontoisena pidetyn aiheen vuoksi: teoksen päähenkilö tuntee vetoa oman sukupuolensa edustajiin, toisiin naisiin. (Ks. Mustola 1996, 96; Pakkanen 2000.) Toisena homoseksuaalisuusaiheiden ennakkosensuroinnin klassikkotapauksena voidaan 
pitää Suomessa Pirkko Saisiota, jota kustantaja pyysi poistamaan esikoisteoksensa Elämänmeno (1975) lesbiset aiheet ennen sen julkaisemista. ${ }^{15}$

Nykyisin, kun ambivalenteista, usein queereiksi ${ }^{16}$ määritellyistä ei-heteroseksuaalisuuden esityksistä on tullut etenkin audiovisuaalisessa mediakulttuurissa mutta myös kirjallisuudessa aikaisempaa yleisempiä, seksuaalisuusaiheiden sensurointi on muuttanut muotoaan. Se ei kohdistu enää varsinaisiin normienvastaisen seksuaalisuuden esityksiin, pikemminkin päinvastoin. Nyt pidetään jopa poliittisesti korrektina sitä, että tehdään näkyväksi heteroseksuaalisuudesta eroavia seksuaalisuuden esityksiä, ja varsinkin viihteessä ja mainonnassa niitä on pidetty uutuudenviehätyksensä, erilaisuutensa, eksoottisuutensa ja jännittävyytensä vuoksi erinomaisina katsojalukujen kasvattajina ja myynninedistäjinä. (Pulkkinen 1993; Mistry 2000; Karkulehto 2001; 2003; 2007b, 13-17.)

Ei-heterot seksuaalisuuden esitykset ovat alkaneet saavuttaa myös julkista arvostusta. Viime vuosina lukuisia kirjallisuuden ja elokuvateollisuuden arvostetuimpia palkintoja on jaettu teoksille, jotka käsittelevät lesbo-, homo-, bi- tai trans-aiheita (Karkulehto 2007b, 14-17). Uralin perhonenkin palkittiin Tampereella parhaana kotimaisena animaationa. Tätä taustaa vasten on kiinnostavaa, että eri taideteoksissa käsitellyt, yhteiskunnallisesti kyseenalaiset seksuaalisuusaiheet tulevat kuitenkin usein häivytetyiksi silloin, kun teoksista kirjoitetaan mediassa, esimerkiksi niitä esittelevissä arvosteluissa. Näin on käynyt muun muassa lesboaiheisille elokuville (ks. Virtanen 1999; Koivunen 2006) sekä esimerkiksi Helena Sinervon Finlandia-palkintoromaanille Runoilijan talossa (2004), jonka päähenkilö on biseksuaali (Karkulehto 2007a).

Runoilijan talossa -romaanin vastaanoton teki vielä hankalammaksi se, että sen biseksuaali päähenkilö on todellinen, historiallisesti merkittävä henkilö: jo edesmennyt, kansallisesti korkealle arvostettu modernistirunoilija EevaLiisa Manner (1921-1995). Kun teoksissa käsitellään todellisia historian henkilöitä, ajatus julkisesti mediassa näkyvän, normienvastaisen seksuaalisuuden ihanteesta ja poliittisesta korrektiudesta näyttääkin kiperöityvän ja monimutkaistuvan. Helsingin Sanomien homo-, lesbo- ja biseksuaalisuuskirjoittelua tutkinut Tuula Juvonen on osoittanut, että nykykulttuurissa queerrepresentaatiot ovat soveliaita silloin, kun kyse on esimerkiksi taiteen ja kulttuurin fiktiivisistä, voyeuristisen katseen kohteiksi asetetuista mediarepresentaatioista, muihin maihin tai menneisyyteen etäännytetyistä henkilöistä, eksotisoinnista tai queeriuden käsittelystä hyvin yleisellä, yksityisyyttä välttelevällä tasolla. Sanomalehdissä on mahdollista kirjoittaa seksuaalivähemmistöistä etäännytetysti ilmiönä. Sen sijaan faktisista ihmisistä ei voida edelleenkään kirjoittaa aina näkyvästi yksilöinä. (Juvonen 2004.)

Suomalaisten sanoma- ja aikakauslehtien biseksuaalisuuskirjoittelua tutkinut Jenny Kangasvuo $(2005,51)$ puolestaan toteaa, että kirjoittelu homoista ja lesboista on tullut mediassa jossain määrin mahdolliseksi ja julkisten representaatioiden piiriin, mutta biseksuaalisuutta käsitellään mediassa edelleen vähän. Queerin julkinen näkyvyys on siis vieläkin rajoittunutta ja kontekstisidonnaista. Niinpä ei ole yllättävää, että kun on kyse lihaa ja verta olleesta suomalaisesta kirjailijasta ja tähän potentiaalisesti liitettävissä olevasta queeriudesta, se pidetään mieluusti kaapissa. Mannerin nimeen yhdistetty avoin heteronormien vastaisesta seksuaalisuudesta kirjoittaminen 
muodostuikin teoksen vastaanotossa lähes mahdottomaksi tehtäväksi, ja aiheesta kirjoittaneet tuntuvat päätyneen usein eräänlaiseen omaehtoiseen ennakko- tai itsesensuuriin. Monet pitivät teoksen kyseenalaiset seksuaalisuusainekset pääosin kaapissa ja korkeintaan häveliäästi vihjailivat niistä. (Karkulehto 2007a.)

Mannerheimista kertovan Uralin perhosen vastaanotossa kävi kuitenkin päinvastoin. Mediassa toistettiin lukuisia kertoja sitä, että Mannerheim esitetään animaatiossa homoseksuaalina. "Homo-Marskia" ei siis piilotettu kaappiin, vaan mediassa julkaistiin kilvan animaatiosta kaapattua kuvaa korsettiin puetusta, samarkandilaisen teehuoneen divaanilla passiivisesti lepäävästä Mannerheim-nukesta sekä tämän seksuaalisesti aktiivisesta Uralin perhonen -palvelija-rakastajasta. Uralin perhosen tapauksessa arkaluontoisina näyttäytyvät, seksuaalisuutta käsittelevät aiheet pistettiin sen vastaanotossa kaapin sijaan suorastaan näytille. Marskin päivät mediamyrskyn silmässä osoittavatkin, että julkinen puhuminen ja kirjoittaminen normienvastaisista seksuaalisuuksista ovat nykyisin jatkuvassa, ainakin tällä hetkellä dynaamiselta näyttävässä prosessissa. (Vrt. Pulkkinen 1993; Karkulehto 2003.) Tämän prosessin moninaisuudesta kertoo, että mediassa syntyi näkyvän ja paikoin markkinahakuisenkin "homo-Marski"-otsikoinnin rinnalle sangen kiintoisa ilmiö, joka muodostui sille samanaikaiseksi, jatkuvaksi Mannerheimin homo- tai biseksuaalisuuden kieltämisen projektiksi. Gustav Hägglund käytti muun muassa A-talk-ohjelmassa (2008) useita puheenvuoroja, joissa hän perusteli Mannerheimin heteroseksuaalisuutta tämän naissankarimaineella sekä tarinalla, jonka mukaan Marski olisi yrittänyt päästä Hägglundin äidinkin hameen alle. Tämän jälkeen uutista Mannerheimista, joka oli yrittänyt iskeä Hägglundin äitiä, toistivat useat lehdet otsikoita myöten:
Hägglundilla vahva käsitys Marskin heteroudesta:"Yritti iskeä omaa äitiäni" / _ - Mun oma äiti kertoi että se yritti iskeä sitä kun hän oli 18-19-vuotias kranssinsitoja yliopistolla. Mun äiti ihmetteli että vieläks tommonen vanha ukko jaksaa olla naisista kiinnostunut, Hägglund muisteli. (Uusi Suomi 2008; ks. myös IL 2008b; Parkkari 2008a.)

Bjarne Kallis taas esitti takeeksi Mannerheimin heteroseksuaalisuudesta kirjaa "Mannerheimin naisista". Lisäksi Iltalehdessä julkaistiin vielä erikseen uutinen Mannerheimin naisystävistä. Uutisessa haastateltiin Mannerheimin elämäkerturi Robert Brantbergia, joka kielsi Mannerheimin homo- tai biseksuaalisuuden mahdollisuuden olemassa olevilla - tai oikeammin olemattomilla - kirjallisilla dokumenteilla:

Olen käynyt todella paljon papereita ja kirjeitä läpi, mutta mitään viittaustakaan marsalkan homo- tai biseksuaalisuudesta ei ole. - - On tietysti helppoa heittää mitä vain, myös hänen ainakin kolmesta sotilaspalvelijastaan, mutta en ole nähnyt yhtä ainoaa dokumenttia sellaisesta. (Tikka 2008b.) 
Elämäkerturille, jonka soisi olevan tietoinen Mannerheimin elämän konteksteista sekä tämän elinaikaan liittyvistä aatteellisista, poliittisista ja lainsäädännöllisistä taustoista, ei tule mieleen, että 1900-luvun alkupuoliskolla sotamarsalkan mahdollinen homo- tai biseksuaalisuus olisi mitä todennäköisimmin ollut yksi valtakunnan varjelluimmista salaisuuksista. On erittäin mahdollista, että siitä ei tarkoituksellisesti jätettäisi jäljelle ainuttakaan dokumenttia. Historiallisen kontekstin huomioon ottamisen sijaan Brantberg vakuutteli Kalliksen ja Hägglundin (A-talk 2008; Parkkari 2008a; Uusi Suomi 2008) tavoin Mannerheimin olleen varsinainen naistenmies, jolla oli todisteena omasta heteroseksuaalisuudestaan paitsi vaimo ja lapsia, myös liuta arvovaltaisia rakastajattaria:

Mannerheim oli naimisissa Anastasia Arapovan kanssa 1892-1919, joskin liitto kylmeni 1903. Heidän tyttärensä Anastasie syntyi 1893, synnytyksessä kuollut poika 1894 ja Sophie 1895. - - Mannerheimin kanssa suhteissa olleiksi tiedetään mm. ensirakkaudet Jeanne Cotta ja Constance Hisinger, kreivitär Jeanne de Salverte, Kitty Linder, Miss Ranska Yvonne la Brousse eli prinsessa Begum Aga Khan, kreivitär Jekaterina Suvalova, ballerina Tamara Karsavina, purjehduksen olympiavoittaja Virginie Heriot, näyttelijä Alla Nazimova sekä myöhäisen iän tuttavuus kreivitär Gertrud Arco auf Valley. / Myös puolalaisruhtinatar Marie Lubomirskan kanssa Mannerheimilla oli traaginen suhde. Se on tunnettu jo pitempään heidän julkaistun intiimin kirjeenvaihtonsa vuoksi. - Mannerheimilla oli tyylikäs naismaku: muuten erityisiä tai kreivittäriä ja ruhtinattaria. (Tikka 2008b.)

"Erityisistä" naisista, kreivittäristä ja ruhtinattarista kootun, hengästyttävän mittaisen Marskin naisseuralaislistan luettelemisen jälkeen Brantberg varmuuden vuoksi lisää, että myös Mannerheimin kaukainen sotilaspalvelija, josta Uralin perhonen ainakin viitteellisesti kertoo, oli tiedetysti perheellinen mies. Näin Uralin perhoseksi nimetty sotilaspalvelijakin näyttäytyy Brantbergin päättelyketjussa pelkästään heteroseksuaalina. Hänen, kuten ei Mannerheiminkaan, homo- tai biseksuaalisuuden kaapissaololle ei tarjota Brantbergin selostuksessa tilaa. (Ks. Tikka 2008b.)

\section{SEKSUAALISUUS JA KANSALLISET KERTOMUKSET}

Nykyisinä median ja julkisuuden intimisoitumisen sekä henkilökohtaistumisen aikoina (Franklin 1997, 4; Karvonen 2006, 17; Ollila 2006, 29) seksistä näyttää tulleen kiinnostavinta julkisuuden henkilöiden elämästä kerrottavaa, tai Michel Foucault'n (1998) seksuaalisuusteorian hengessä paljastettavaa, sisältöä (Ollila 2006, 32-33; Juntunen \& Väliverronen 2008, 87). Tuntuukin epäjohdonmukaiselta, miten edellä viittaamassani, suhteellisen tuoreessa Eeva-Liisa Manneriin liittyneessä tapauksessa (bi)seksuaalisuudesta tuli jotain, mitä piti julkisesti salailla ja kiertää. Samoin kummastuttavaa on, että yhtäältä Mannerheimin mahdollisella homoseksuaalisuudella spekuloitiin julkisesti taajaan ja toisaalta se myös kiellettiin julkisuudessa jatkuvasti. Mikä näitä ilmiöitä voisi selittää? 
Maija-Riitta Ollilan näkemys nykymediassa julkisuuden henkilöihin liitetyistä seksipaljastuksista näiden arvon ja uskottavuuden kyseenalaistajina voisi olla yksi selittävä tekijä (Ollila 2006, 31-33; ks. myös Juntunen \& Väliverronen 2008, 89). Ollilan näkemystä soveltaen julkiset esitykset Mannerin ja Mannerheimin seksuaalisuudesta ikään kuin tekevät heidät henkilöinä arvottomiksi ja epäuskottaviksi, jopa epäilyttäviksi. Tämän yhdistäminen heidän kansalliseen merkittävyyteensä muodostuu vastaanotossa hankalaksi yhtälöksi. Merkitystä on silläkin, että Manner on yksi Suomen kanonisoiduista kirjailijoista, joka siten väistämättä kertoo kirjallisuudellaan ja kirjailijuudellaan suomalaisuudesta (Kirstinä 2007, 11-12; ks. myös esim. Hämäläinen 2005; Vialva 2004) ja että Mannerheim luetaan Suomen"merkkihenkilöksi" (esim. Ilaskivi 2008), "kansallissankariksi" (esim. AL 2008c, d, e) "suurimmaksi suomalaiseksi kautta aikojen", Suomen pelastajaksi" ja "Suomen itsenäisyyden symboliksi" (A-talk 2008). Runoilijan talossa-romaanin ja Uralin perhonen -animaation päähenkilöt ovat todellisia, Suomen historiassa ja kirjallisuushistoriassa merkittäviä henkilöitä, joiden tehtävänä on kuvastaa ja ilmentää joko kirjallisella tuotannollaan tai koko olemuksellaan myös suomalaisuutta.

Stuart Hallin (2003, 96-97) mukaan kulttuuristen kertomusten tehtävänä on vaalia kansallista yhteenkuuluvuuden tunnetta häivyttämällä kulttuurin sisäiset, muun muassa luokkaan, alueeseen, "rotuun", sukupuoleen ja seksuaalisuuteen liittyvät erot. Tavoitteena on salata, verhota ja vaientaa se tosiasia, että kulttuurit eivät koskaan ole monoliitteja, vaan koostuvat eroavaisuuksista ja yhtäläisyyksistä, jatkuvuuksista ja uusista osasista, joita leimaavat katkokset sekä erityisesti erot. Tähän yhtenäisen kansakunnan kertomukseen Runoilijan talossa ja Uralin perhonen sekä niiden esittämä kuva heteronormatiivisuutta vastustavasta kaanonkirjailijasta ja kansallissankarista eivät oikein mahdu. Kun kirjallisuusinstituutiossa kanonisoidun, kansallisesti merkittävän runoilijan ja kansallisen sotasankarin normienvastainen ja heidät henkilöinä kyseenalaiseksi asettava seksuaalisuus on vaarassa rinnastua myös Suomen kansaan, seksuaalisuusaiheiden sensurointi, niiden kielellinen ja retorinen kaapittamisprosessi, tuleekin tiettyjen tahojen näkökulmasta tarpeelliseksi vielä nyky-Suomessa, joka on muuten jo hyvinkin monenkirjavien queer-seksuaalisuuksien esitysten kyllästämää. (Karkulehto 2007b, 184-189.)

Lisäksi Uralin perhosen tapauksessa ongelmiksi nousivat Mannerheimin seksuaalisuuteen intersektionaalisesti yhdistyvät sukupuoli ja etnisyys. ${ }^{17}$ "Överiksi menee, jos joku kirgiisi bylsii Suomen tulevaa presidenttiä", sanoo paljonpuhuvasti Hägglund (A-talk 2008). Mannerheimin seuralaisen, kirgisialaisen Uralin perhosen etnisyys tuo kimurantisti näkyväksi myös Mannerheimin oman etnisyyden, vaikka se valkoisena jättäytyykin helposti näkymättömäksi (vrt. Dyer 2002, 180). Samoin Uralin perhosen moninkertainen kansallinen, etninen ja seksuaalinen toiseus ja ulkopuolisuus asettavat väistämättä esille myös Mannerheimin, kansallissankarimme, historiallisen ulkopuolisuuden, vierauden ja toiseuden suomalaisessa yhteiskunnassa. Tästä on yleensä oltu kansallisissa suurmieskertomuksissa vaiti. Mannerheimin vastaanottava, passiivinen ja penetroitava seksuaalisuus puolestaan esittelee feminiinisyyteen viittaavan passiivisen maskuliinisuuden, joka rinnastuu animaation aktiivisiin naisiin ja aktiiviseen feminiinisyyteen ja sekoittaa siten 
perinteisiä sukupuolirooleja. Näin Uralin perhonen haastaa seksuaalisuuden ja kansallisuuden ohessa kulttuurisia sukupuolen ja etnisyyden rajoja.

Näyttäisi siltä, että esimerkiksi Hägglund ja Kallis peräsivätkin sekä printti-, digitaalisessa että audiovisuaalisessa mediassa (mm. A-talk 2008; IS 2008a; Kallis 2008) animaation olemassaolon oikeutusta lähinnä siksi, että se ei vastaa kansallisen historian kanonisoitua tarinaa. Vaihtoehtoisille historioille tai ohjaaja-Lillqvistin toivomalle, vaikeista asioista ääneen puhumisen mahdollistavalle mannermaiselle keskustelutyylille (ks. Hemming 2008), saatiin silti onneksi joissain artikkeleissa ja $A$-talk-keskustelussa aika ajoin tilaa. Sen sijaan A-talk-keskustelun jälkeiset, Kalliksen blogissaan kirjoittamat puheenvuorot kielivät jostain aivan muusta, lähinnä homofobialla ryyditetystä, yhtenäisen kansakunnan ihanteen ja sitä kuvaavien kansallissankari-illuusioiden varjelusta:

Keskiviikko 2.7. / Luin eilisen lehdestä, että minut, ylipormestari Raimo Ilaskivi ja kenraali Gustav Hägglund oli palkittu arvonimellä"Kunniarotta". - - Arvonimen myönsi Seta (Seksuaalinen tasavertaisuus ry). / Seta perusteli päätöstään vetoamalla lausuntoihin, joita olimme antaneet keskustelussa, jota käytiin Mannerheimista kertovan animaatiofilmin tiimoilta. Kritisoimme lausunnoissamme sitä, että marsalkka Mannerheim esitettiin elokuvassa homoseksuaalina. Sitä ei voinut Setan väki suvaita. Samoin emme mekään voineet hyväksyä sitä, että Mannerheim, jonka Suomen kansa on valinnut kaikkien aikojen suurimmaksi suomalaiseksi, leimattiin seksuaalisesti poikkeavaksi.

-.

Maanantai 11.8. / Venäjällä on pystytetty kiertävä marsalkka Mannerheimiä koskeva näyttely. - - [N]äyttely antoi - - Mannerheimista täysin toisenlaisen kuvan kuin se, joka paljon huomiota herättänyt animaatioelokuva pyrkii hänestä antamaan. / En voi ymmärtää enkä hyväksyä sitä, että valtion varoilla tuetaan animaatioelokuvaa, joka kuvaa Suomen kautta aikojen suurimman suomalaisen lahtarina ja homona. Animaatioelokuvan tuottajan kannattaisi käydä näyttelyssä. Ehkä se saisi hänet häpeämään tekojaan. (Kallis 2008.)

Ainakin näissä puheenvuoroissa Lillqvistin toivoma keskustelun mannermaisuus vyörytetään pikemminkin yhteen totuuteen uskovalla mannerheimlaisuudella eli kansallisella suurmieskertomuksella, jonka tavoitteena on häivyttää kulttuurin sisäiset, erityisesti seksuaalisuuteen liittyvät erot. Samalla Kalliksen teksteissä palataan takaisin lähtöruutuun: siinä missä Hägglund kehotti Lillqvistiä häpeämään heti Uralin perhosta ja Marskia koskevan mediamyrskyn alussa, Kallis tekee sen ikään kuin kokoavana sulkeumana myrskyn päätteeksi, lähes puoli vuotta Yleisradion A-talkissa yhdessä käydyn keskustelun jälkeen. 


\section{MITÄ MUUTA MYRSKYN JÄLKEEN?}

Olen esittänyt tässä artikkelissa kysymyksen, miksi Uralin perhonen sai osakseen niin kiihkeän mediavastaanoton ja kuohutti monien tunteita. Yksi syy on varmasti se, että kun kulttuuri- ja mediasodissa ja niihin kytkeytyneissä sensuurikeskusteluissa yleensä on kyse joko seksuaalisuuteen, uskontoon, politiikkaan tai yhteiskunnalliseen valtaan liittyvistä, arkaluontoisina tai kyseenalaisina pidetyistä asioista (Hurri 1993, 290-291; Sedergren 2004, 273; Ekholm 2005), Uralin perhonen täytti kaikki nämä kulttuurisodille ja niihin liittyneille sensurointikeskusteluille esitetyt kriteerit. Se on koettu Suomen kansan suurimmaksi suomalaiseksi valitsemaa henkilöä rienaavaksi, se käsittelee provokatiivisesti häneen liitettyä seksuaalisuutta ja se uudelleen- tai toisinkirjoittaa vähintäänkin yhtä provokatiivisesti kansallista historiaa - ja useiden mielestä loukkaa siten kokonaista sukupolvea.

Myös uskonto on Uralin perhosessa ja sen vastaanotossa läsnä. Lillqvistin tapausta on kiinnostavaa verrata Rannan Muhammed-sarjakuvaan ja sen julkaisemisen aikaiseen, maailmanlaajuiseen Muhammed-kohuun. Siinä missä Rannan työ käsitteli pelkoa ja sananvapautta suhteessa uskontoon, ja tanskalaisille, muslimiyhteisöjä loukkaavien Muhammed-kuvien piirtäjille langetettiin fatwa-tuomioita, Lillqvist on saanut animaationsa julkaisemisen jälkeen jopa tappouhkauksia (Lillqvist 2008a, b; Roth \& Nyrhinen 2008; YLE Uutiset 2008). Näin näyttäisi käyneen lähinnä siksi, että Suomessa kirjaimellisesti heti jumalasta seuraavaksi asetettu Mannerheim, jota verrataan sananmukaisesti "kristukseen", "pyhään" ja jopa itse jumalaan ("Gud") (AL 2008g; MTV3-STT 2008; Dahlbäck 2008; ks. myös AL 2008c, d, e; Ilaskivi 2008; IS 2008a; Salminen 2008), oli puettu punaiseen korsettiin ja hänen suhteensa Uralin takaa tuotuun paimenpoika-palvelijaan esitettiin homoeroottisena. Uralin perhosen vastaanotossa katsottiin, että Mannerheimiin liitetty homo- tai biseksuaalisuus ja transvestisuus uhkaavat laskea hänet uskonnolliseen merkkihenkilöön rinnastettavissa olevan kansallissankarin jalustalta. Samansuuntaista Mannerheim-ihannoinnin uskontoon vertaavaa pohdintaa on tehnyt Jarkko Silén:

Suurimmaksi suomalaiseksi valtiollisen yleisradioyhtiön äänes-
tyksessä nostettuun Mannerheimiin yllättävän monet ihmiset
näyttävät kuitenkin suhtautuvan uskonnollisesti - aivan kuin
mitään todellista, edes kuviteltua ihmistä, ei pitäisi tämän san-
karihahmon takaa yrittääkään etsiä. Kuvaavaa on, että elokuvaa
on sananvapausmielessä verrattu profeetta Muhammedista teh-
tyihin tietoisesti rienaaviiin karikatyyreihin. (Silén 2008.)

Sen lisäksi, että Lillqvistin työn loukkaavuus rinnastettiin Muhammedsarjakuvajupakkaan, sitä on arvosteltu sankaruus- ja isänmaaretoriikan ohessa uskonnollisen retoriikan avulla (esim. A-talk 2008; Dahlbäck 2008). Lillqvist on itse verrannut animaationsa sensuurivaateita fundamentalistisen islamistivaltion sensuuriin, ja Facebookissa hänelle langetettiin jo fatwakin tosin (onneksi) vain vitsinä. (AL 2008b; Lillqvist 2008a, b; Roth \& Nyrhinen 2008; YLE Uutiset 2008.) Gayle S. Rubin totesi jo neljännesvuosisata sitten kaukonäköisessä artikkelissaan "Thinking Sex" (1984/1993, 3-4),

Tiedotustutkimus 2008:5 
että silloiset seksuaalisia arvoja koskevat konfliktit muistuttavat aiempien vuosisatojen uskonnollisia kiistoja. Nykyisin niihin ladataan aina vain suurempi määrä emotionaalista kiihkeyttä ja ne saavat yhteiskunnassa entistä suuremman symbolisen arvon (ks. myös Juvonen 1999, 49), ja sen Uralin perhosenkin tapaus osoittaa.

Kulttuurisodissa usein mukana kulkevan sensuroinnin tai sen tavoittelun ja sillä spekuloinnin yhteydessä on myös huomattavaa, että sensuuri toimii, aivan kuten esimerkiksi propaganda, muutamien yleistysten ja iskusanojen varassa. Monimutkaiset perustelut ja tieteelliset argumentit kuuluvat kulttuurisotiin ja niihin yhteydessä oleviin sensurointipyrkimyksiin harvoin, mikä on huolestuttavaakin lähinnä siksi, että niihin liittyy aina valtakysymyksiä ja vallankäytön mekanismeja. (Ekholm 2005.) Taiteesta käydyt, sen sensuroimista vaativat tai sellaisella spekuloivat keskustelut ovat yhteiskunnallista vaikuttamista ja vallankäyttöä. Niillä vaikutetaan muun muassa käsityksiimme "hyvästä" ja hyväksyttävästä sekä "huonosta" ja paheksuttavasta taiteesta. Taiteen arvottamisen ohessa kulttuurisodat ja taiteen sensurointivaateet näyttävät tuottavan näkemyksiä myös "hyvästä" ja hyväksyttävästä sekä "huonosta" ja paheksuttavasta seksuaalisuudesta, uskonnosta, kansallisuudesta ja kansallishistoriasta. Marskin päivät mediamyrskyn silmässä osoittavat, että varsin monille suomalaisen sotasankaruuden, kansallishistorian ja kansallisuuden täytyy "hyvinä” pysyäkseen näyttäytyä edelleen muuttumattomina, järkkymättömästi pyhinä ja jalustalle asetettuina ihannekuvina, joita taiteen ei sovi horjuttaa.

Paradoksaalisesti juuri Uralin perhosesta mediassa käyty arvokeskustelu tai kulttuurisota, jos asia niin halutaan muotoilla - on kuitenkin osaltaan vaikuttamassa sen arvostukseen. Harri Kalha puhuu Havis Amandan vastaanoton tarkastelun yhteydessä "kulttuurin diskursiivisesta perusolemuksesta", jonka mukaisesti taideteoksesta käyty julkinen keskustelu väistämättä myös lisää sen relevanssia. Hänen mukaansa taidetta kritisoivakin keskustelu kasvattaa sen arvoa sillä, että se ylipäätään tulee kriittisen keskustelun piiriin. Niin sanotut protektionistiset asenteet paitsi "rasittavat" myös "rikastavat" kulttuuria, sanoo Kalha. Asenteisiin kytkeytyy toki konservatismia ja vieraan torjuntaa, mutta samalla ne tuottavat myös elävää kulttuurikeskustelua ja jopa kiinnostusta keskusteluissa torjuttua toiseutta kohtaan. (Kalha 2008, 15, 181.) Tässä valossa "homo-Marskin" päiviä mediamyrskyn silmässä voidaan lukea myös toisin kuin olen edellä tehnyt. Uralin perhosen ristiriitainen vastaanotto toki osoittaa, että normienvastaisia seksuaalisuuksia on hankala käsitellä suhteessa suomalaiseen sotasankaruuteen, kansallishistoriaan ja kansallisuuteen, jotka näyttäytyvät monissa yhteyksissä edelleen muuttumattomina, järkkymättömästi pyhinä ja jalustalle asetettuina ihannekuvina. Myrsky osoittaa selvästi, ettei taiteen tai sen esittelemien normienvastaisten seksuaalisuuksien sovi horjuttaa näitä kuvia.

Toisaalta Uralin perhosen vastaanotosta virinnyttä mediamyrskyä voidaan kuitenkin lukea myös seksuaalisuuden kulttuurisia merkityksiä ja rajoja koettelevana ilmiönä. Se on tuottanut elävää kulttuurikeskustelua, tarjonnut normienvastaisten seksuaalisuuksien esityksille arvokasta mediatilaa ja herättänyt toivon mukaan jopa kiinnostusta keskusteluissa torjuttua toiseutta kohtaan. Näin se on väistämättä myös rikastanut suomalaista nykykulttuuria. 
1 Kiitän nimettömäksi jääviä refereitä sekä teemanumeron toimittajia artikkelikäsikirjoitustani koskevista kommenteista ja korjausehdotuksista, joiden myötä sen alkuperäinen versio on kokenut perustavanlaatuisen muodonmuutoksen.

2 Suomen vuoden 1918 tapahtumien tutkimuksessa on kiistelty pitkään siitä, tulisiko niistä puhua vapaussotana, luokkasotana, kansalaissotana, vallankumouksena, kapinana, sisällissotana vai jonain niiden johdannaisena. Nykyisin tapahtumista käytetään suhteellisen yksimielisesti nimityksiä sisällissota ja kansalaissota. (Salminen 2007, 199.)

3 Sellaiset STT:n uutiset, jotka julkaistiin samanlaisina useiden lehtien verkkosivuilla, olen poiminut mukaan vain kerran. Aiheesta uutisoiva lehti on valikoitunut aineistoon satunnaisesti. Olen merkinnyt lehden lähdeviitteeseen seuraavasti (esim.): ILSTT 2008. Uutisten ja artikkelien lisäksi aineistossa on joitakin blogi- ja internetsivustotekstejä (Hämäläinen 2007; Ilaskivi 2008; Kallis 2008; Kristillisdemokraatit 2008; Lillqvist 2008a, b). internet-keskustelupalstoilla esitettyjä yleisöpuheenvuoroja (esim. Aamulehti 2008; HS.fi 2008; Ilta-Sanomat 2008 a, b; KSML.fi 2008; Savon Sanomat 2008) en ole tässä yhteydessä tutkinut. Niiden - samoin kuin animaation vastaanoton toisen kipupisteen, Mannerheimin roolin sisällissodassa - analysoiminen tuottaisi jatkossa tärkeää, laajennettua tietoa Uralin perhosen vastaanotosta.

4 Kiitän Anna Moringia A-talk-ohjelman tallentamisesta ja kopioimisesta käyttööni.

5 Määrittelen sananvapauden Merja Hurrin $(1993,56,280)$ ja Kalevi Haikaran (1984, 9) tapaan mielipiteen- ja ilmaisunvapaudeksi. En siis rajoita sitä pelkästään esimerkiksi journalistiseen vapauteen (vrt. Hemánus 1983). Taiteen vapauden on puolestaan todettu olevan lainsäädännöllisesti sananvapauttakin kattavampaa, vaikka se usein julkisesti kyseenalaistetaankin (Rautiainen 2007; 2008; Tontti 2008).

6 Kai Ekholmin (2005) mukaan sensuroinnissa on kyse toiminnasta, jonka tarkoituksena on muuttaa tai estää tekoja tai ajatuksia, joiden katsotaan olevan yhteiskunnallisesti, sosiaalisesti ja poliittisesti niin sanotun yhteisen edun vastaisia. Tavallisimmin sensuuri on sanallisen tai kuvallisen materiaalin poistamista ihmisten saatavilta. Nimitän kaikkia tässä artikkelissa esillä olevia eri taiteenlajien - esimerkiksi kirjallisuuden, sarjakuvan, kuva- ja valokuvataiteen sekä audiovisuaalisen median - sensuroimis- tai sensurointipyrkimys- ja spekulaatioprosesseja yhtenäisesti kulttuurisensuureiksi. Luen kulttuurisensuureihin myös lehdistöön kohdistetut sensurointitoimet. Sensuuri voidaan jakaa ainakin kolmeen osa-alueeseen, joita ovat ennakko-, jälki- ja itsesensuuri. Ennakkosensuuri on sanallisen ja kuvallisen materiaalin osittaista tai täydellistä poistamista jo ennen sen julkaisemista, kun taas jälkisensuurissa poistaminen tehdään julkaisemisen jälkeen. Itsesensuurissa on kyse tekijän itsensä toteuttamasta sanallisen ja kuvallisen materiaalin tarkoituksellisesta poisjättämisestä. Se on siis tavallaan ennakkosensuurin alakategoria. Merja Hurrin (1993, 284, 290) ja Pertti Hemánuksen (1983, 166-176) mukaan esimerkiksi journalistisessa itsesensuurissa on kyse "kirjoittamattomasta ohjesäännöstöstä" tai "tahdikkuussäännöstöstä", jonka tehtävänä on mahdollistaa journalistien työskentely tietyn kulttuurin rajoissa ja ylipäätään journalistin ammatissa. Sensurointipyrkimykset tai -spekulaatiot puolestaan ovat julkista keskustelua, neuvottelua ja argumentaatiota, joiden tavoitteena on jonkun materiaalin ennakko- tai jälkisensuuri. Toisinaan nämä pyrkimykset ja spekulaatiot tuottavat tulosta, toisinaan taas eivät. Luen tässä artikkelissa sensuroinnin piiriin laajasti myös sellaiset teokset, joita ei ole varsinaisesti koskaan sensuroitu, mutta joiden ympärillä on käyty kiivasta kulttuurisotaa ja joita on pyritty sensuroimaan, joiden sensuroinnilla on spekuloitu tai joita on suoraan ehdotettu poistettavaksi ihmisten saatavilta. Tällöin sensurointikeskusteluihin lukeutuu myös Uralin perhonen, jonka rahoitus haluttiin toistuvasti kyseenalaistaa ja jota vaadittiin sensuroitavaksi (AL 2008a, c, d, g, h; A-talk 2008; Ilaskivi 2008; Ilta-Sanomat 2008a; Kallis 2008; Kristillisdemokraatit 2008; MTV3-STT 2008; Parkkari 2008b).

7 Ks. homoseksuaalisuuteen viittaavista otsikoista edellä mainittujen lisäksi myös AL 2008e; Dahlbäck 2008; IS 2008b; Kerttula \& Peltomäki 2008; Koponen 2008b; Määttänen 2008; Paasonen 2008b; Parkkari 2008b; Tikka 2008a. 
8 Puhuessani poliittisuudesta tarkoitan sillä Michel Foucault'hon (1998) viitaten tuottavaa valtaa ja toimintaamme diskursiivisen vallan verkostoissa, joihin kaikki ovat kiinnittyneinä, halusivatpa he sitä tai eivät. Kysymys on siis representaatioiden ja diskurssien politiikasta - siitä, etteivät representaatiot, diskurssit saati tiedontuotanto voi ylipäätäänkään olla objektiivisia tai neutraaleja, toisin sanoen epäpoliittisia. (Ks. myös esim. Horsti 2002; Rastas 2007.)

9 Virasto totesi 4.7.2008 kirjatun uutisen mukaan, ettei Yleisradio syyllistynyt kunnianloukkaukseen esittäessään animaation (HS.fi-STT 2008; IS 2008b).

10 Homo-, lesbo-, bi-, trans- ja queer-representaatioiden saavuttamasta suosiosta ja jopa arvostuksesta nykymediassa ks. esim. Pulkkinen 1993; Mistry 2000; Roseneil 2000; Juvonen 2004; Kangasvuo 2005; Karkulehto 2001; 2003; 2007b, 13-16; Koivunen 2006; Rossi 2007.

11 Rannan sarjakuvassa profeetta Muhammed esitetään provokatiivisesti naamari päässä siksi, ettei hänen kasvojaan saa kansainvälisen, tanskalaisen Jyllands Posten -lehden käynnistämän Muhammed-pilapiirroskohun jälkeen piirtää (ks. aiheesta lisää, Journalismikritiikin vuosikirja 2007). Karttusen teoksen kielletyksi aineistoksi muodostuivat internetin luvattomilta sivuilta printatut, lapsipornoa esittelevät kuvat, joiden tehtävänä oli kritisoida lapsipornon helppoa saatavuutta nykyisessä mediayhteiskunnassa (Mellais ym. 2008; Sevänen 2008; Tontti 2008). Vastaavanlaisen kulttuurisodan synnyttivät mm. vuonna 1969 Harro Koskisen sikateokset, jotka esittivät ristiinnaulittua sikamessiasta ja Suomen vaakunan leijonan tilalle asetettua sikaa. Koskinen tuomittiin jumalanpilkasta ja Suomen vaakunan epäisänmaallisesta häpäisemisestä. (Sedergren 2004, 276; Tontti 2008; Sevänen 2008.) Tuoreimmassa taiteen sensuroimisen rajoja koetelleessa tapauksessa Yhteisvastuukeräys poistatti marraskuussa 2008 kahden taiteilijan teokset Toiseuden kohtaaminen -taidenäyttelystään, joka oli lähdössä kiertämään Suomen seurakuntia ja kirkkoja. Jari Järnströmin ja Viggo Wallensköldin maalaukset poistatettiin Kirkkopalvelut ryःn kuvataidetyöryhmä Seccon kokoamasta näyttelystä, koska ne määriteltiin transseksuaalisuutta, alastomuutta ja "miehen himoa" esittelevinä sopimattomiksi seurakuntatiloihin. Teosten poistaminen näyttelystä nostatti kohun, jonka myötä Yhteisvastuukeräyksen henkilöstö päätyi kompromissiin: Järnström ja Wallensköld voisivat osallistua näyttelyyn, mutta vain teoksilla, joissa ei esitellä miesten sukupuolielimiä eikä homoseksuaalisuutta. (Lehtinen 2008a, b; Vänskä 2008.)

12 Rannan sarjakuva julkaistiin Kaltion kotisivuilla, mutta lehden hallitus vaati päätoimittajaa poistamaan sen. Päätoimittajan kieltäytyminen johti hänen erottamiseensa ja sarjakuvan poistamiseen sivuilta. Sarjakuva löytyy nykyisin Rannan kotisivuilta osoitteesta http://www.villeranta.com/nettijulkaisut/muhammed.

13 Väkivalta on elokuvien sensuroinnissa keskeinen määrittelijä seksin ja politiikan ohella (Maasilta 2007, 190). Uusiksi sensurointia sivuaviksi ja sen kysymyksiä huomattavasti monimutkaistaviksi alueiksi ovat esimerkiksi journalismissa nousseet myös "rotu" ja etnisyys, joiden esittäminen mediassa kietoutuu monesti varsin kyseenalaisella tavalla myös rasismiin ja rasismin historiaan (ks. esim. Rastas 2007; Kunelius 2007).

14 Suomessa on esitetty vastaavanlaisia anteeksipyyntöjä ennenkin. Esimerkiksi vuonna 1951 Suomen ulkoministeriö pahoitteli Yhdysvaltain Helsingin-suurlähettiläälle sitä, ettei Suomen elokuvasensuuri voi kieltää kaikkea neuvostoliittolaista, lännenvastaista propagandaa (Sedergren 2004, 271).

15 Saisio (2000, 352-353) kirjoittaa tästä ennakkosensuurista Miten kirjani ovat syntyneet -kokoelmassa (ks. myös esim. Pakkanen 2000; Kivilaakso 2007).

16 Tarkoitan queerilla heteronormatiivisuutta ja normatiivista heteroseksuaalisuutta kyseenalaistavia seksuaalisuuksia.

17 Intersektionaalisuudesta ja sen taustoista ks. esim. Rossi 2008. 


\section{Tutkimusaineisto}

Aamulehti (2008) Keskustelu. Puheenaihe: Mannerheim ja animaatioelokuva Uralin perhonen. http://www.aamulehti.fi/keskustelu/forum.jspa?forumID=523 (linkki tarkistettu 14.10.2008).

AL (2008a) Ei voi olla totta: Homo-Marski tukki koko teatterin! Aamulehti.fi 29.2.2008. http://www.aamulehti.fi/teema/mannerheim/71919.shtml (linkki tarkistettu 14.10.2008).

AL (2008b) Facebookissa leviää"pilafatwa" Marski-filmin tekijälle. Aamulehti.fi 27.2.2008. http://www.aamulehti.fi/teema/mannerheim/71344.shtml (linkki tarkistettu 14.10.2008).

AL (2008c) Hägglund Mannerheim-animaatiosta: "Puna-armeijan propagandan perillinen". Aamulehti.fi 24.2.2008. http://www.aamulehti.fi/teema/mannerheim/70699.shtml (linkki tarkistettu 14.10.2008).

AL (2008d) Reservin vääpeli närkästyi Mannerheim-animaatiosta. Aamulehti.fi 24.2.2008. http://www.aamulehti.fi/teema/mannerheim/70698.shtml (linkki tarkistettu 25.11.2008).

AL (2008e) Yle ei esitä "homo-Mannerheimia" itsenäisyyspäivänä. Aamulehti 24.2.2008. http://www.aamulehti.fi/teema/mannerheim/70800.shtml (linkki tarkistettu 17.9.2008).

AL (2008f) Katariina Lillqvist ryöpyttää Hägglundia. Aamulehti.fi 24.2.2008. http://www. aamulehti.fi/teema/mannerheim/katariina-lillqvist-ryopyttaa-hagglundia/70828 (linkki tarkistettu 14.10.2008).

AL (2008g) Taistelupari: Gustav Hägglund - Katariina Lillqvist. Aamulehti 26.2.2008. Aamulehti.fi 7.3.2008. http://www.aamulehti.fi/teema/mannerheim/73056.shtml (linkki tarkistettu 14.10.2008).

AL (2008h) Mannerheim-kohuanimaatio kuohuttaa - katso näyte elokuvasta. Aamulehti. fi 7.3.2008. http://www.aamulehti.fi/teema/mannerheim/mannerheim-kohuanimaatiokuohuttaa-katso-nayte-elokuvasta/71918 (linkki tarkistettu 14.10.2008).

A-talk (2008) A-talk 6.3.2008. Yleisradio TV1.

Avola, Pertti (2008) Uralin perhonen nousee kansanperinteestä. Helsingin Sanomat 29.2.2008. http://www.hs.fi/kulttuuri/artikkeli/Uralin+perhonen+nousee+kansanperin teest\%C3\%A4/1135234454709 (linkki tarkistettu 25.11.2008).

Dahlbäck, Nina (2008) “Som att säga att Gud är homofil”. HBL 26.2.2008. http://www. hbl.fi/text/inrikes/2008/2/26/w10583.php (linkki tarkistettu 10.12.2008).

Earl, Lilli (2008) Elokuva-arvio: Uralin perhonen. Uusi Suomi 27.2.2008. http://www. uusisuomi.fi/kulttuuri/16202-elokuva-arvio-uralin-perhonen (linkki tarkistettu 25.11.2008).

Hemming, Mia (2008) "Uralin perhosen juuret ovat Suomen kansan kertomaperinteessä." Kritiikin uutiset 1/2008. http://www.katariinalillqvist.com/haastattelu.htm (linkki tarkistettu 14.9.2008).

HS.fi (2008) Kerro mielipiteesi Mannerheim-animaatiosta. HS.fi 29.2.2008. http:/ /www. hs.fi/keskustelu/message.jspa?messageID=1815338 (linkki tarkistettu 14.10.2008).

HS.fi-STT (2008) Marski-animaatiosta tehty kantelu ei johda toimenpiteisiin. HS.fi 4.7.2008. http://www.hs.fi/kotimaa/artikkeli/Marski-animaatiosta+tehty+kantelu+ei+j ohda+toimenpiteisiin/1135237653110 (linkki tarkistettu 25.11.2008).

Hällsten, Annika (2008) Mannerheim som docka är känsligt stoff. HBL 28.2.2008. http:// www.hbl.fi/text/kultur/2008/2/28/d10693.php (linkki tarkistettu 10.12.2008).

Hämäläinen, Unto (2007) Tiistai 6.2.2007/23.merkintä. http://blogit.hs.fi/unski/tiistai62200723merkinta/\#more-128 (linkki tarkistettu 3.7.2008).

IL (2008a) Homo-Mannerheim kohauttaa Ylen ohjelmassa! Iltalehti.fi 23.2.2008. http:// www.iltalehti.fi/uutiset/200802237290182_uu.shtml (linkki tarkistettu 14.10.2008).

IL (2008b) Lehti: Mannerheim yritti iskeä Gustav Hägglundin äitiä. Iltalehti.fi 7.3.2008. http://www.iltalehti.fi/viihde/200803077355515_vi.shtml (linkki tarkistettu 14.10.2008.)

Ilaskivi, Raimo (2008) Mannerheimin häpäisijöitten päät pölkylle! Uusi Suomi 25.2.2008. http://www.uusisuomi.fi/nakokulmat/raimoilaskivi/mannerheimin-hapaisijoitten-paatpolkylle (linkki tarkistettu 14.10.2008). 
Ilta-Sanomat (2008a) Lukijan ääni. Nostot. Ansaitseeko Uralin perhonen Oscarin vaiko esityskiellon? http://keskustelut.iltasanomat.fi/thread.jspa?threadID $=5158$ (linkki tarkistettu 14.10.2008).

Ilta-Sanomat (2008b) Keskustelu. Lukijan ääni. Onko Marskin seksuaalisuudella merkitystä? http://keskustelut.iltasanomat.fi/thread.jspa?threadID $=4851$ (linkki tarkistettu 14.10.2008).

IL-STT (2008) Mannerhemin-elokuva täytti katsomon Tampereella. Poliittinen elokuva kiinnostaa - ainakin jos se käsittelee Mannerheimin seksuaalista suuntautuneisuutta. Iltalehti.fi 29.2.2008. http://www.iltalehti.fi/uutiset/200802297320901_uu.shtml (linkki tarkistettu 25.11.2008).

IS (2008a) Hägglund Mannerheim-animaation ohjaajalle: Saisi hävetä. Ilta-Sanomat

23.2.2008, http://www.iltasanomat.fi/uutiset/kotimaa/uutinen.asp?id=1492210 (linkki tarkistettu 14.10.2008).

IS (2008b) Animaation homo-Mannerheim ei loukannut kunniaa. Ilta-Sanomat 4.7.2008. http://www.iltasanomat.fi/uutiset/kotimaa/uutinen.asp?id=1552724 (linkki tarkistetu 14.10.2008).

Kallis, Bjarne (2008) Bjarnen nettipäiväkirja. http://www.bjarnekallis.net/f/etusivu/ nettipaivakirja/?id=67 (linkki tarkistettu 14.10.2008).

Kerttula, Suvi \& Peltomäki, Tuomas (2008) Homoyhteisössä Mannerheimin homoudesta on huhuttu jo pitkään. HS.fi 14.3.2008. http://www.hs.fi/kulttuuri/artikkeli/Homoyhteis\%C 3\%B6ss\%C3\%A4+Mannerheimin +homoudesta+on+huhuttu+jo+pitk\%C3\%A4\%C3\%A4 n/1135234807912 (linkki tarkistettu 25.11.2008).

Koponen, Taneli (2008a) Kohuohjaaja:"Mannerheim istuu helvetin kiirastulessa". Aamulehti 24.2.2008. http://www.aamulehti.fi/teema/mannerheim/70697.shtml (linkki tarkistettu 14.10.2008).

Koponen, Taneli (2008b) Mannerheim on animaatiossa homo. Aamulehti 6.3.2008. http:// www.aamulehti.fi/teema/mannerheim/73057.shtml (linkki tarkistettu 14.10.2008).

Kristillisdemokraatit (2008) Tietoinen tavoite loukata. Kristillisdemokraattien internetsivut 28.2.2008. http://www.kristillisdemokraatit.fi/KD/www/fi/ajankohtaista/blogit/ paivirasanen/index.php?we_objectID=1471 (linkki tarkistettu 14.8.2008).

KSML.fi (2008) Keskustelu. Uralin perhonen. http://www.ksml.fi/mielipide/keskustelu/ Uralin-perhonen-(lillqvist)-jauhaa-paskaa.....(87839).ece (linkki tarkistettu 14.10.2008).

Lillqvist, Katariina (2008a) Hei kaikki kulttuuriväki. http://www.mtv3.fi/uutiset/kulttuuri. shtml/arkistot/kulttuuri/2008/02/617969 (linkki tarkistettu 14.10.2008).

Lillqvist, Katariina (2008b) Tiukalle nyöritetty tasavalta eli kuinka kenraali pillastui kentaurille. http://www.cameracagliostro.fi/suomi/uralin-perhonen.htm (linkki tarkistettu 14.10.2008).

MTV3.fi (2008) Marski-animaation ohjaajalta raivokas puolustuskirje. MTV3.fi 29.2.2008. http://www.mtv3.fi/uutiset/kulttuuri.shtml/arkistot/kulttuuri/2008/02/617969 (linkki tarkistettu 14.8.2008).

MTV3-STT (2008) "Homo-Marski" herätti pahennusta myös eduskunnassa. MTV3.fi 28.2.2008. http://www.mtv3.fi/uutiset/arkisto.shtml/arkistot/kotimaa/2008/02/617540 (linkki tarkistettu 14.8.2008).

Määttänen, Markus (2008) Brokeback Mountain Uralilla. Aamulehti 1.3.2008. http://www. aamulehti.fi/teema/mannerheim/73053.shtml (linkki tarkistettu 25.11.2008).

Paasonen, Anna (2008a) Kohuanimaatio kuvaa Tampereen ja Marskin suhdetta. MTV3.fi 3.3.2008. http://www.mtv3.fi/uutiset/kulttuuri.shtml/arkistot/kulttuuri/2008/03/618750 (linkki tarkistettu 14.10.2008).

Paasonen, Anna (2008b) Marski - lahtarikenraalista homoksi. MTV3.fi 29.2.2008. http:// www.mtv3.fi/uutiset/kulttuuri.shtml/arkistot/kulttuuri/2008/02/617807 (linkki tarkistettu 14.10.2008).

Parkkari, Jani (2008a) Hägglund: Mannerheim yritti iskeä äitini! Ilta-Sanomat 7.3.2008. http://www.iltasanomat.fi/uutiset/kotimaa/uutinen.asp?id=1497515 (linkki tarkistettu 14.10.2008).

Parkkari, Jani (2008b) Kenraali ja kansa raivostuivat elokuvan homo-Mannerheimista. IltaSanomat 25.2.3008. http://www.iltasanomat.fi/uutiset/ kotimaa/ uutinen.asp?id=1492574 (linkki tarkistettu 14.10.2008).

Roth, Seppo \& Tiina Nyrhinen (2008): Ilaskivi vaatii Marskin häpäisijän päätä pölkylle. Aamulehti 7.3.2008. http://www.aamulehti.fi/teema/mannerheim/73055.shtml (linkki tarkistettu 14.10.2008). 
Räikkä, Jyrki (2008) Katariina Lillqvist tekee nukeilla poliittista taidetta. Helsingin Sanomat

29.2.2008, http://www.hs.fi/kulttuuri/artikkeli/Katariina+Lillqvist+tekee+nukeilla+p oliittista+taidetta/1135234454810 (linkki tarkistettu 12.10.2008).

Salminen, Satu (2008) Mannerheim on elokuvassa homo. Ilta-Sanomat 23.2.2008. http:// www.iltasanomat.fi/uutiset/kotimaa/uutinen.asp?id=1492035 (linkki tarkistettu 14.10.2008).

Savon Sanomat (2008) Keskustelu. Uralin perhosesta. http://www.savonsanomat.fi/ mielipide/keskustelu/URALIN-PERHOSESTA(86666).ece (linkki tarkistettu 14.10.2008).

Silén, Jarkko (2008) Uralin perhonen - legenda ja myytinmurtaja. Film-O-Holic. com 13.3.2008. http://www.film-o-holic.com/palsta/artikkelit/uralin_perhonen.htm (linkki tarkistettu 14.8.2008).

Taponen, Aki (2008) Marskin sali ei ole vastaisku animaation nukkehahmolle. Aamulehti. fi 5.3.2008. http://www.aamulehti.fi/teema/mannerheim/marskin-sali-ei-ole-vastaiskuanimaation-nukkehahmolle/72771 (linkki tarkistettu 15.10.2008).

Tikka, Juha-Pekka (2008a) Jungner: Yle ei esitä "homo-Marskia" itsenäisyyspäivänä. Ilta-Sanomat 24.2.2008. http://www.iltasanomat.fi/uutiset/kotimaa/uutinen. asp?id=1492424 (linkki tarkistettu 14.8.2008).

Tikka, Juha-Pekka (2008b) IS esittelee Mannerheimin naiset - katso kuvat. Ilta-Sanomat 19.3.2008. http://www.iltasanomat.fi/uutiset/kotimaa/uutinen.asp?id=1506813 (linkki tarkistettu 14.8.2008).

Tolonen, Ruut (2008) "Surettaa, mutta tärkeintä on sananvapaus". Aamulehti 1.3.2008. http://www.aamulehti.fi/teema/mannerheim/al-132008-surettaa-mutta-tarkeinta-onsananvapaus/73052 (linkki tarkistettu 14.10.2008).

TS (2008) Nukke- Mannerheimista sananvapauskiista. Turun Sanomat 26.2.2008. http://www.turunsanomat.fi/kulttuuri/?ts $=1,3: 1005: 0 ; 0,4: 5: 0: 1: 2008-02-26,104: 5: 5$ 21688,1:0:0:0:0:0: (linkki tarkistettu 14.10.2008).

Uralin perhonen (2008) Uralin perhonen. Nukkeanimaatio. Ohj. Katariina Lillqvist. Tuotanto Camera Cagliostro, Film Co-operative. Suomi.

Uusi Suomi (2008) Hägglundilla vahva käsitys Marskin heteroudesta:"Yritti iskeä omaa äitiäni". Uusi Suomi 7.3.2008. http://www.uusisuomi.fi/kotimaa/16996hagglundilla-vahva-kasitys-marskin-heteroudesta-\%E2\%80\%9Dyritti-iskea-omaaaitiani\%E2\%80\%9D (linkki tarkistettu 14.10.2008).

YLE Uutiset (2008) Mannerheim-animaation tekijälle tappouhkauksia. YLE Uutiset 29.2.2008. http://www.yle.fi/uutiset/kulttuuri/oikea/id84026.html (linkki tarkistettu 15.6.2008)

\section{Kirjallisuus}

Dyer, Richard (2002) Älä katso! Seksuaalisuus ja rotu viihteen kuvastossa. Toim. Martti Lahti. Tampere: Vastapaino.

Ekholm, Kai (2005/1997) Kielletyt kirjat. Jyväskylän yliopiston kirjasto. http://jyk.jyu.fi/ jyk/kokoelmat/julkaisut/kielletyt_kirjat/ (linkki tarkistettu 14.10.2008).

Foucault, Michel (1998) Seksuaalisuuden historia, osat I, II, III: Tiedontahto, Nautintojen käyttö, Huoli itsestä (Histoire de la Sexualité I, II, III, 1976, 1984, 1984). Suom. Kaisa Sivenius. Helsinki: Gaudeamus.

Franklin, Bob (1997) Newszak and News Media. London: Arnold.

Haikara, Kalevi (1984) Kuka surmasi sananvapauden. Muistokirjoitus. Helsinki: Otava.

Hall, Stuart (2003) Kulttuuri, paikka, identiteetti (New Cultures for the Old, 1995). Suom. Juha Koivisto. Teoksessa Lehtonen, Mikko \& Olli Löytty (toim.) Erilaisuus. Tampere: Vastapaino, 85-130.

Hemánus, Pertti (1983) Journalistinen vapaus. Helsinki: Gaudeamus.

Horsti, Karina (2002) Maahanmuuttajajournalismi - välivaihe monikulttuuriseen journalismiin. Teoksessa Raittila, Pentti (toim.) Etnisyys ja rasismi journalismissa. SJL:n Mediakriittinen julkaisusarja 6. Tampere \& Helsinki: Journalismin tutkimusyksikkö, Tampereen tiedotusopin laitos ja Suomen Journalistiliitto, 109-144. 
Hurri, Merja (1993) Kulttuuriosasto. Symboliset taistelut, sukupolvikonflikti ja sananvapaus viiden pääkaupunkilehden kulttuuritoimituksissa 1945-80. Acta Universitatis Tamperensis ser A vol 389. Tampereen yliopisto.

Hämäläinen, Helvi (2001) Kaunis sielu. Helsinki: WSOY.

Hämäläinen, Timo (2005) Myyrän hysteria. Helsingin Sanomat 20.10.2005, 23.

Journalismikritiikin vuosikirja (2007) Satu Seppä (toim.): Journalismikritiikin vuosikirja 2007. Tiedotustutkimus 1/2007. Tampere: Journalismin tutkimusyksikkö.

Juntunen, Laura \& Esa Väliverronen (2008) Lemmenkipeä media villiintyi pääministerin morsiamesta. Teoksessa Jaakkola, Maarit (toim.) Journalismikritiikin vuosikirja 2008. Tiedotustutkimus 2/2008. Tampere: Journalismin tutkimusyksikkö, 8-20.

Juvonen, Tuula (1999) Mitäs nyt suuhun pannaan. Naistutkimus 4/1999, 49-53.

Juvonen, Tuula (2002) Varjoelämää ja julkisia salaisuuksia. Tampere: Vastapaino.

Juvonen, Tuula (2004) Nyt se näkyy, nyt taas ei. Heteronormatiivisuus ja homoseksuaalisuuden esillepano Helsingin Sanomissa. Tiedotustutkimus 2/2004, 34-55.

Kalha, Harri (2008) Tapaus Havis Amanda. Siveellisyys ja sukupuoli vuoden 1908 suihkulähdekiistassa. Helsinki: SKS.

Kangasvuo, Jenny (2005) Wanna be bi? Biseksuaalisuus suomalaisessa lehdistössä. Teoksessa Karkulehto, Sanna \& Kati Valjus (toim.) Valtamedia/Vastamedia. Kirjoituksia mediakulttuurista. Acta Universitatis Ouluensis, Humaniora B 59. Oulun yliopisto, 51-68.

Karkulehto, Sanna (2001) "Alas heterojen fasistinen oikeaoppisuus." Queer as Folk -sarjan politiikkaa ja estetiikkaa. Lähikuva 1/2001, 25-39.

Karkulehto, Sanna (2003) Unisex-tuotteista unisex-wc:ihin. Queer-estetiikka osana jälkimodernia viihde- ja kulutusteollisuutta. Teoksessa Heikkinen, V.A. (toim.) Kameleonttikuluttaja ikuista mielihyvää ja unelmaa etsimässä. Helsinki: Haaga Research Center, 36-45.

Karkulehto, Sanna (2007a) Kaapista kaanoniin - ja takaisin. Helena Sinervon Runoilijan talossa -romaanin vastaanotto. Kulttuurintutkimus 3/2007, 3-20.

Karkulehto, Sanna (2007b) Kaapista kaanoniin ja takaisin. Johanna Sinisalon, Pirkko Saision ja Helena Sinervon teosten queer-poliittisia luentoja. Acta Universitatis Ouluensis B81. Oulun yliopisto.

Karvonen, Erkki (2006) Karpelan kujanjuoksu ja hutkivat journalistit. Teoksessa Seppä, Satu (toim.) Journalismikritiikin vuosikirja 2006. Tiedotustutkimus 1/2006. Tampere: Journalismin tutkimusyksikkö, 8-20.

Kekki, Lasse (2006) Kirjat kaapista: lesbo- ja homokirjallisuuden lajia etsimässä. Teoksessa Hypén, Kaisa (toim.) Fiktiota! Levottomat genret ja kirjaston arki. Helsinki: BTJ Kirjastopalvelu, 85-94.

Kirstinä, Leena (2007) Kansallisia kertomuksia. Suomalaisuus 1990-luvun proosassa. Helsinki: SKS.

Kivilaakso, Katri (2007) Pirkko Saision tuotanto ja julkisuus - "Mikä elävän sanan kriteeri?" Teoksessa Mustola, Kati \& Johanna Pakkanen (toim.) Sateenkaari-Suomi. Seksuaali- ja sukupuolivähemmistöjen historiaa. Helsinki: Like, 266-270.

Koivunen, Anu (2006) Queer-feministinen katse elokuvaan. Teoksessa Mäkelä, Anna; Liina Puustinen \& Iiris Ruoho (toim.) Sukupuolishow. Johdatus feministiseen mediatutkimukseen. Helsinki: Gaudeamus, 80-106.

Kunelius, Risto (2007) “Anteeksi vaan Voltaire”. Tiedotustutkimus 1/2007, 20-41.

Kuronen, Susan (2007) Pääministerin morsian. Helsinki: Etukeno.

Lehtinen, Aki Petteri (2008a) Seksuaalivähemmistöt eivät mahdu kirkon toiseusnäyttelyyn. HS.fi 17.11.2008.

Lehtinen, Aki Petteri (2008b) Kirkon Toiseus-näyttelystä poistetut pääsevät mukaan. Helsingin Sanomat 29.11.2008.

Linna, Väinö (1954) Tuntematon sotilas. Porvoo: WSOY.

Lyytikäinen, Pirjo (2004) Peiliin piirretty nykyaika. Teoksessa Saarikangas, Kirsi; Pasi Mäenpää \& Minna Sarantola-Weiss (toim.) Suomen kulttuurihistoria 4. Koti, kylä, kaupunki. Helsinki: Tammi, 211-224.

Maasilta, Mari (2007) African Carmen. Transnational Cinema as an Arena for Cultural Contradictions. Media Studies. Tampere University Press.

Mellais, Maritta; Max Ryynänen; Martta Heikkilä \& Irmeli Hautamäki (2008) Skandaalista toiseen. Keskustelun koonnut Martta Heikkilä. Mustekala.info 4.6.2008. Taide, politiikka, kansainvälisyys 3/08, Volume 28. http://www.mustekala.info/node/711 (linkki tarkistettu 14.10.2008). 
Mistry, Reena (2000) From “Heart and Home” to a Queer Chic: A Critical Analysis of Progressive Depictions of Gender in Advertising. http://www.theory.org.uk/mistry.htm (linkki tarkistettu 7.8.2004).

Mustola, Kati (1996) Syöjättärestä naapurintytöksi - naisia rakastavia naisia ennen vuotta 1971 suomeksi julkaistussa kaunokirjallisuudessa. Teoksessa Hekanaho, Pia Livia; Kati Mustola; Anna Lassila \& Marja Suhonen (toim.) Uusin silmin. Lesbinen katse kulttuuriin. Helsinki University Press, 67-113.

Mäki, Teemu (2005) Kissa. Teoksessa Mäki, Teemu: Näkyvä pimeys. Esseitä taiteesta, filosofiasta ja politiikasta. Helsinki: Like/Kuva, 76-102.

Ollila, Maija-Riitta (2006) Luonnetestejä vai savuverhoja: yksityisyys mediassa. Journalismikritiikin vuosikirja 2006. Tiedotustutkimus 1/2006. Tampere: Journalismin tutkimusyksikkö, 28-37.

Pakkanen, Johanna (2000) Kadotettua lesbokirjallisuutta etsimässä. Raijakoo. Feministinen mielipide- ja kulttuurilehti 2/2000. http://gamma.nic.fi/ raijakoo/johanna.htm (linkki tarkistettu 17.7.2007).

Pulkkinen, Tuija (1993) Keinotekoista seksiä? Luonto, luonnottomuus ja radikaali sukupuolipolitiikka. Tiede \& edistys 3/1993, 298-313.

Rastas, Anna (2007) Neutraalisti rasistinen? Erään sanan politiikkaa. Teoksessa Kuortti, Joel; Mikko Lehtonen \& Olli Löytty (toim.) Kolonialismin jäljet. Keskustat, periferiat ja Suomi. Tampere: Vastapaino, 119-141.

Rautiainen, Pauli (2007) Taiteen vapaus perusoikeutena. Helsinki: Taiteen keskustoimikunta.

Rautiainen, Pauli (2008) Mitä oikeastaan on taiteen vapaus? Arsis 2/2008, 22-24.

Roseneil, Sasha (2000) Postmoderneja seksuaalisuuden muutoksia: Queer viitekehyksenä ja vaikutteena. Naistutkimus-Kvinnoforskning, 2/2000, 28-42.

Rossi, Leena-Maija (2007) Queer TV? Kumouksellisten representaatioiden politiikasta ja ehdoista. Teoksessa Rossi, Leena-Maija \& Anita Seppä (toim.) Tarkemmin katsoen. Visuaalisen kulttuurin lukukirja. Helsinki: Gaudeamus 2007, 122-136.

Rossi, Leena-Maija (2008) Identiteetti, queer ja intersektionaalisuus - hankala yhtälö? Kulttuurintutkimus 1/2008, 29-39.

Rubin, Gayle S. (1984/1993) Thinking Sex: Notes for a Radical Theory of the Politics of Sexuality. Teoksessa Abelove, Henry; Michéle Aina Barale \& David M. Halperin (toim.) The Lesbian and Gay Studies Reader. New York: Routledge, 3-44.

Saisio, Pirkko (1975) Elämänmeno. Helsinki: Kirjayhtymä.

Saisio, Pirkko (2000) Pirkko Saisio. Teoksessa Haavikko, Ritva (toim.) Miten kirjani ovat syntyneet 4. Virikkeet, ainekset, rakenteet. Helsinki: WSOY, 343-369.

Salama, Hannu (1964) Juhannustanssit. Romaani. Helsinki: Otava.

Salminen, Esko (2003) Suomalaisen sensuurin läpileikkaus. Teoksessa Salonharju, Inkeri (toim.) Kirja tietoverkkojen maailmassa. Helsinki: Helsingin yliopiston kirjasto. http://www.lib. helsinki.fi/julkaisut/kirjatietoverkkojenmaailmassa/ ISBN 951-10-1320-6 (linkki tarkistettu 18.9.2008).

Salminen, Esko (2007) Päättymätön sota 1918. Sisällissota julkisessa sanassa 1917-2007. Helsinki: Edita.

Sedergren, Jari (2004) Vaarallinen taide ja kansakunnan rajat. Teoksessa Saarikangas, Kirsi; Pasi Mäenpää \& Minna Sarantola-Weiss (toim.) Suomen kulttuurihistoria 4. Koti, kylä, kaupunki. Helsinki: Tammi, 268-276.

Seppä, Satu (2007) Toimittajalta. Teoksessa Seppä, Satu (toim.) Journalismikritiikin vuosikirja 2007. Tiedotustutkimus 1/2007. Tampere: Journalismin tutkimusyksikkö, 64.

Sevänen, Erkki (2008) Ei ole ennalta määrättyjä taiteen keinoja. Mustekala.info Päätoimittaja blogi 8.4.2008. http://www.mustekala.info/node/682 (linkki tarkistettu 8.9.2008).

Tontti, Jarkko (2008) Pääkirjoitus. Taiteen vapaus jälleen uhattuna. Kiiltomato 26.2.2008. http://www.kiiltomato.net/?cat=editorial\&id=156 (linkki tarkistettu 14.10.2008).

Vialva, Sonja (2004) Eeva-Liisa Manner ja matkallaolon taide. http://www.kultti.net/ jutut/2004/9_eeva-liisa.html (linkki tarkistettu 28.8.2006).

Virtanen, Ilona (1999) Fucking Åmål - lesboelokuva joka makuun. Lähikuva 2-3/1999, 78-88.

Vänskä, Annamari (2008) Official otherness? SQS: Journal of Queer Studies in Finland 2/2008, 73-76. 